\title{
Hf isotope compositions of northern Luzon arc lavas suggest involvement of pelagic sediments in their source
}

Jean-Christophe Marini ${ }^{1}$, Catherine Chauvel ${ }^{1}$ and René C. Maury ${ }^{2}$

${ }^{1}$ : LGCA, Université Joseph Fourier, Maison des Géosciences, BP 53, F-38041 Grenoble Cedex 09, France

${ }^{2}$ : IUEM, Université de Bretagne Occidentale, Place N. Copernic, F-29280 Plouzané, France

Corresponding author: Catherine Chauvel, E-mail: Catherine.Chauvel@ujf-grenoble.fr Tel.: 33 (0)4 766359 12; Fax: 33 (0)4 76514058

Words counts: Abstract: 164 words, text: $\approx 7242$ words 


\begin{abstract}
New Hf isotopic compositions for island arc basalts from the Luzon arc (Philippines) define a remarkable sub-horizontal trend in Hf-Nd isotopic space with a small range of $\varepsilon_{\mathrm{Hf}}(+5$ to +17$)$ associated with a large variation in $\varepsilon_{\mathrm{Nd}}(-7$ to +8$)$. The data plot above and barely overlap the terrestrial array defined by oceanic basalts and continental crust. Mixing hyperbola passing through the data intersect fields for depleted mantle and pelagic sediments suggesting that these two components formed the source of the Luzon arc lavas. An exception is the Batan Island where the low $\varepsilon_{\mathrm{Nd}}$ ratios are associated with low $\varepsilon_{\mathrm{Hf}}$ values. A mixing hyperbola fitting the Batan samples suggests that their mantle source was modified by subducted material prior to contamination by terrigenous clays.

The relationship between $\mathrm{Nd}$ and $\mathrm{Hf}$ isotopic compositions in the Luzon volcanics show that the type of sediment subducted under an island arc is a determining factor in the control of the two isotopic systems in island arc environments.
\end{abstract}

\title{
Introduction
}

Subduction zones are important sites of the Earth surface because they are regions where continental crust is extracted from the mantle. Petrological and geochemical studies show that island arc lavas have compositions that approach that of average continental crust (Taylor and McLennan 1985; Taylor and McLennan 1995) but differ significantly from those of lavas at mid-ocean ridges or in oceanic islands such as Hawaii. Possible explanations for the close similarities between the compositions of continental crust and island arcs are not yet fully developed but they can be separated into two distinct categories: (a) The distinctive chemical characteristics of both arcs and the continental crust (negative $\mathrm{Nb}$ - $\mathrm{Ta}$ anomalies and enrichment of the LILE) is a primary feature unique to magma formation in subduction zones. These features are bequeathed to the continental crust as island arcs are accreted and reworked during crust-forming processes. (b) The chemical characteristics of arc magmas are secondary, being inherited from sediments of continental origin. The continental signature is transmitted from subducted sediment to the mantle source of arc magmas as the sediments dehydrate or partially melt during the subduction process. It is very likely that both explanations are valid; the continental signature was created initally in ancient subduction zones, then recycled each 
time a new subduction zone forms. The critical question is the relative importance of the two processes in modern subduction zones. While the presence of ubiquitous and large negative $\mathrm{Nb}$ anomalies in arcs showing otherwise little to no involvement of sediments in their source argue in favor of specific fractionation processes during arc lava formation (McCulloch and Gamble 1991; Elliott et al. 1997), other studies have demonstrated that the composition of subducted sediments strongly influences the composition of the island arc basalts (White and Dupré 1986; McDermott et al. 1993; Plank and Langmuir 1993; Vroon et al. 1993; Vroon et al. 1995). The question remains therefore open.

Because Hf is a high field strength element (HFSE) and Nd is a rare earth element (REE), they behave differently during sedimentary processes. Hf is concentrated in zircon which is deposited as a detrital component, typically in coarser-grained terrigenous sediments; $\mathrm{Nd}$ is present mainly in clay minerals which are deposited in finer-grained sediments or in chemical precipitates. Detrital sediments therefore have high $\mathrm{Hf} / \mathrm{Nd}$ and low $\mathrm{Lu} / \mathrm{Hf}$ ratios which leads to non-radiogenic $\mathrm{Hf}$ isotope ratios while pelagic sediments and Fe-Mn crusts and nodules have low $\mathrm{Hf} / \mathrm{Nd}$ and high Lu/Hf which generate more radiogenic Hf with time (Patchett et al. 1984; White et al. 1986; Ben Othman et al. 1989; Godfrey et al. 1997; Albarède et al. 1998; Vervoort et al. 1999; David et al. 2001). The Hf-Nd isotopic array of arc lavas will therefore depend on the type of sediment subducted under the arc. Similarly, the process responsible for the addition of sediments to the source of arc lavas will affect the Nd-Hf isotopic relationship. Because $\mathrm{Nd}$ is more soluble than $\mathrm{Hf}$ in aqueous fluids, dehydration of sediments and/or basaltic crust will favor $\mathrm{Nd}$ input relative to $\mathrm{Hf}$ while bulk melting should transfer both elements in relatively unchanged proportions (Tatsumi et al. 1986; McCulloch and Gamble 1991; Saunders et al. 1991; Hawkesworth et al. 1993a; Hawkesworth et al. 1993b; Hawkesworth et al. 1994; Pearce et al. 1999). This process also has consequences on the Nd$\mathrm{Hf}$ isotopic array in the arc lavas. In summary, both the contribution to the arc source of a subducted material with variable $\mathrm{Nd}-\mathrm{Hf}$ isotopic compositions, and the various processes affecting the REE and HFSE in subduction zones are potential causes of Nd-Hf geochemical and isotopic variations in arc lavas.

Very few studies have focussed on the Hf isotopic compositions of island arc basalts (White and Patchett 1984; Salters and Hart 1991; Vroon et al. 1998; Pearce et al. 1999; Woodhead et al. 2001) and much understanding of the processes occurring under the arcs can be gained by further work. The Luzon arc is an excellent site to evaluate Nd-Hf isotopic systematics in arcs because this arc displays a very large range of Nd isotopic compositions (Defant et al. 1989; Defant et al. 1990; McDermott et al. 1993; Fourcade et al. 1994). This suggests that Hf 
isotopic compositions should also vary widely. Previous authors have suggested the involvement of different types of sediments in the source, terrigenous sediments in the opinion of McDermott et al. (1993) and pelagic sediments for Fourcade et al. (1994) . Various mechanisms for the transfer of the sedimentary component from slab to wedge were also suggested: aqueous fluid transfer in the opinion of Maury et al. (1992) and siliceous melts for Bau and Knittel (1993), Schiano et al. (1995), Maury et al. (1998), Prouteau et al. (1999) and Sajona et al. (2000). Combining Hf isotopic compositions with previously published traceelement and $\mathrm{Nd}$ isotope data should therefore help constrain the source composition and the processes involved in the formation of the Luzon arc.

\section{Geological setting}

The Luzon arc extends from Luzon, the northernmost island of the Philippines archipelago to Taiwan in the West Pacific (Fig. 1). It includes many active or dormant volcanoes distributed over about $1200 \mathrm{~km}$ between Taiwan and Mindoro Islands and it formed through the eastward subduction of the South China Sea beneath the Luzon plate (Hayes and Lewis 1984; Stephan et al. 1986; Teng 1990; Huang et al. 1997). The subduction of the South China oceanic lithosphere is limited in the north by the collision between the arc and the Chinese continental platform and in the south by the Mindoro collision zone.

The basement of the volcanoes is exposed in Luzon Island where it consists of Cretaceous ophiolites overlain by volcanoclastic sediments (Pubellier et al. 1996). No old continental crust basement has been described in our study area in the northern part of the Luzon arc. We selected 19 basalts, basaltic andesites and andesites from the islands of Lutao, Lanshu, Batan, Babuyan, Calayan and Camiguin in the northern part of the Luzon arc and from Mount Cagua and Baguio volcanoes on Luzon island. Their ${ }^{40} \mathrm{~K}-{ }^{40} \mathrm{Ar}$ radiometric ages, determined on whole rock samples by Richard et al. (1986a and b), Defant et al. (1990) and Maury et al. (1998), range from 5.7 Ma to 1480 years B.P. (Table 1).

\section{Previous work}

Several recent papers have concentrated on the petrologic, geochemical and isotopic characteristics of volcanics from the northern part of the Luzon arc (Richard et al. 1986a; 
Richard et al. 1986b; Jacques 1987; Defant et al. 1989; Vidal et al. 1989; Chen et al. 1990; Defant et al. 1990; McDermott et al. 1993; Fourcade et al. 1994; Maury et al. 1998). These studies show that basalts and andesites from the Luzon arc have major element compositions ranging from low-K tholeiites to high-K calc-alkaline lavas. They also display a large variety of trace element patterns, ranging from nearly flat patterns in the arc tholeiites to patterns strongly enriched in large ion lithophile elements (LILE) and light rare earth elements (LREE) in the high-K calc-alkaline volcanics. Their $\mathrm{Sr}, \mathrm{Nd}$ and $\mathrm{Pb}$ isotopic compositions are also highly variable (Defant et al. 1989; Vidal et al. 1989; Chen et al. 1990; Defant et al. 1990; McDermott et al. 1993). For example in a ${ }^{143} \mathrm{Nd} /{ }^{144} \mathrm{Nd}$ versus ${ }^{87} \mathrm{Sr} /{ }^{86} \mathrm{Sr}$ diagram (Fig. 4 of McDermott et al. (1993)) the Luzon volcanics range from values close to those of MORB $\left({ }^{87} \mathrm{Sr} /{ }^{86} \mathrm{Sr}=0.703\right.$ and $\left.{ }^{143} \mathrm{Nd} /{ }^{144} \mathrm{Nd}=0.5131\right)$ in the arc tholeiites to enriched compositions $\left({ }^{87} \mathrm{Sr} /{ }^{86} \mathrm{Sr}=0.706\right.$ and $\left.{ }^{143} \mathrm{Nd} /{ }^{144} \mathrm{Nd}=0.5123\right)$ in the calc-alkaline lavas.

\section{Analytical procedure}

On the basis of published $\mathrm{Nd}$ isotopic compositions (Defant et al. 1990; McDermott et al. 1993; Fourcade et al. 1994), we selected 19 samples and analysed them for Hf isotopes. Chemical separation was carried out in Grenoble following the procedure described by Blichert-Toft et al. (1997) and measurements were performed using the VG Plasma 54 in Lyon. Blanks were negligible relative to the amount of Hf present in the samples and the average measured ${ }^{176} \mathrm{Hf} /{ }^{177} \mathrm{Hf}$ ratio for the standard JMC 475 was $0.282165 \pm 10$ (1б, 17 runs). The Hf isotopic compositions are reported in Table 1.

Some trace element concentrations for our samples were published by Defant et al. (1990) and McDermott et al. (1993) but data were not complete. We therefore measured trace element concentrations by ICP-MS in Grenoble. The analytical procedure was described by Barrat et al. (1996) but the following modifications were added: a larger number of trace elements was measured and no chemical separation followed sample dissolution. As in Barrat et al. (1996), BHVO-1 was used for calibration of the machine and reported concentrations are relative to the BHVO-1 composition given in Table 1. Values measured for other standards are also reported in Table 1. 


\section{Results}

\section{A - Hf isotopic composition of the Luzon volcanics}

Lavas from the Luzon arc have ${ }^{176} \mathrm{Hf} /{ }^{177} \mathrm{Hf}$ ratios ranging from $0.283251\left(\varepsilon_{\mathrm{Hf}}=+16.9\right)$ to $0.282693\left(\varepsilon_{\mathrm{Hf}}=-2.8\right)$ (Table 1). The arc tholeiites have the most radiogenic Hf isotopic compositions whereas the high-K calc-alkaline lavas have the lowest $\varepsilon_{\mathrm{Hf}}$ values. These Hf isotopic compositions are very different from those measured in other volcanic rocks. For example, in an $\varepsilon_{\mathrm{Hf}}$ versus $\varepsilon_{\mathrm{Nd}}$ diagram, even samples with low $\varepsilon_{\mathrm{Nd}}$ values have radiogenic $\mathrm{Hf}$ isotopic ratios (Fig. 2). Samples from the northern and the southern Luzon islands define two roughly parallel arrays, both of which have significantly lower slopes than that defined by other terrestrial samples including MORB, OIB, continental crust and other island arcs (Patchett and Tatsumoto 1980; White and Patchett 1984; Salters and Hart 1991; Vervoort et al. 1999).

The only samples that do not fall in the subhorizontal field are the Batan island volcanics. These samples have low $\varepsilon_{\mathrm{Hf}}(-3$ to -1$)$ associated to low $\varepsilon_{\mathrm{Nd}}(-5$ to -2$)$, values comparable to those reported by White and Patchett (1984) for the Banda arc (Fig. 2).

\section{$B$ - Trace element composition of the Luzon volcanics}

Measured trace element concentrations are listed in Table 1 and plotted in Fig. 3. The new data confirm the geochemical features measured previously. The Luzon rocks show a large range of trace element concentrations, from arc tholeiites moderately enriched in LILE and LREE to high-K calc-alkaline lavas strongly enriched in LILE and LREE relative to HREE. They are also characterized by strong depletions in $\mathrm{Nb}$ and Ta relative to the neighbouring incompatible trace elements. These depletions increase from arc tholeiites which have $\mathrm{La} / \mathrm{Nb}$ ratios of about 2 to high $\mathrm{K}$ calc-alkaline samples with $\mathrm{La} / \mathrm{Nb}$ ratios of 11 (see also Fig. 3). A positive $\mathrm{Pb}$ anomaly is present in all trace element patterns and it translates into low $\mathrm{Ce} / \mathrm{Pb}$ ratios of 2.3 to 6.7 , values that are much lower than the $\mathrm{Ce} / \mathrm{Pb}$ ratio of about 25 found in MORB and OIB (Hofmann et al. 1986).

Additional features of Luzon arc lavas are illustrated in Figure 4. Three groups can be identified when $\mathrm{Hf}$ isotopic compositions are used in conjunction with $\mathrm{Sm} / \mathrm{Hf}, \mathrm{Pb} / \mathrm{Hf}$ and $\mathrm{Sr} / \mathrm{Hf}$ ratios: 
- Lavas from volcanoes in the southern part of the study area (Baguio, Cagua, Camiguin, Calayan + sample Bb 39 for Babuyan) have highly radiogenic Hf isotopic compositions $\left(\varepsilon_{\mathrm{Hf}}\right.$ from +13 to +17 ) combined with a large range of $\mathrm{Sm} / \mathrm{Hf}$ ratios (between 1 and 2.1) and a relatively small range of $\mathrm{Nd} / \mathrm{Hf}$ (3.5 to 8.9).

- Lavas from the northern part of the arc (Lutao and Lanshu islands) have lower $\varepsilon_{\mathrm{Hf}}$ values (between +5 and +11 ) and they show a restricted range of $\mathrm{Sm} / \mathrm{Hf}$ ratios (1.1 to 1.6). Their $\mathrm{Nd} / \mathrm{Hf}$ ratios vary from 4.9 to 14.6 .

- Batan Island defines a third group with the lowest $\varepsilon_{\mathrm{Hf}}$ values and a restricted range of Sm/Hf and $\mathrm{Nd} / \mathrm{Hf}$ ratios (1.1 to 1.6 and 6.4 to 8.3 respectively, see Fig. $4 a$ ).

The trace element signature of Luzon lavas have some other interesting characteristics. As shown in Fig. 5, samples from the northern and southern island groups display significant $\mathrm{Ce}$ negative anomalies that correlate with the Hf isotopic compositions. In contrast, Batan lavas, which have the lowest $\mathrm{Hf}$ isotopic compositions of our data set display no significant $\mathrm{Ce}$ anomalies.

\section{Discussion}

\section{A- Contamination of the mantle source or assimilation within the arc crust?}

The Luzon arc volcanics have $\mathrm{Sr}, \mathrm{Nd}$ and $\mathrm{Pb}$ isotopic compositions that extend from isotopic ratios close to MORB to isotopic ratios close to continental material (Defant et al. 1989; Vidal et al. 1989; Chen et al. 1990; Defant et al. 1990; McDermott et al. 1993; Fourcade et al. 1994). These features are commonly attributed to variable proportions of sedimentary material in the mantle source rather than to the assimilation of wall rocks during magma ascent through the arc crust. We believe that the compositions of Luzon volcanics are not solely due to crustal contamination for the following reasons:

1) When the Luzon arc started to form in the Middle Miocene ( $\approx 20 \mathrm{Ma}$ ago), it was located on the Philippines oceanic plate far away from any continental detrital source (Hall et al. 1995; Lee and Lawver 1995). The basement of the arc consists therefore of oceanic crust and it is not covered by a thick pile of continental sediments (Defant et al. 1990). 
2) McDermott et al. (1993) showed that the lavas with the lowest $\varepsilon_{\mathrm{Nd}}$ are also the most magnesian. This is the opposite of what could be expected during assimilation and fractionation processes within the crust.

3) The presence of mantle xenoliths in some Batan lavas (Richard et al. 1986b) suggests a rapid ascent of the magmas through the arc crust and argues against contamination during magma ascent.

4) $\mathrm{Nd}$ and $\mathrm{Hf}$ isotopes as shown in Figure 2 lie on an array significantly above the terrestrial array. To produce this array by crustal contamination would require an extremely peculiar composition for the underlying crust, a composition with high ${ }^{176} \mathrm{Hf} /{ }^{177} \mathrm{Hf}$ and low ${ }^{143} \mathrm{Nd} /{ }^{144} \mathrm{Nd}$ that has never reported for any crustal material.

Consequently, the enriched signature of the lavas cannot be attributed to contamination by the arc crust and its origin has to be found in the source region.

\section{$B$ - Mixing processes in the arc source}

Numerous studies have demonstrated that the chemical and isotopic compositions of arc lavas reflect contamination of their mantle source by the materials recycled through the subduction zone (Gill 1981; Hawkesworth et al. 1993a). The arc source corresponds to a mixture of multiple components: the subarc mantle and materials coming from the subducted basaltic crust and overlying sediments (Ellam and Hawkesworth 1988; Hawkesworth et al. 1993a; Turner et al. 1996; Elliott et al. 1997; Class et al. 2000).

In the Luzon arc, the $\mathrm{Sr}, \mathrm{Nd}$ and $\mathrm{Pb}$ isotopic compositions of the volcanic rocks show clearly that sedimentary material is present in their source (Defant et al. 1989; Vidal et al. 1989; Chen et al. 1990; Defant et al. 1990; McDermott et al. 1993; Fourcade et al. 1994). This suggestion is confirmed and reinforced by the Ce anomalies shown in Fig. 5. Similar negative $\mathrm{Ce}$ anomalies were also reported for the Mariana arc lavas where they were cited as decisive evidence for the involvement of sedimentary materials in the source of the lavas (Hole et al. 1984; Woodhead 1989; Lin 1992; Elliott et al. 1997). The presence of similar negative Ce anomalies in the Luzon arc volcanics implies that sediments were also present in the source of Luzon lavas, but this does not preclude that, as suggested by some authors, other components from the subducted basaltic crust could also have contaminated the mantle wedge under the 
arc (Maury et al. 1992; McDermott et al. 1993; Schiano et al. 1995; Maury et al. 1998; Prouteau et al. 1999; Sajona et al. 2000).

Using the relationship between $\mathrm{Nd}$ and $\mathrm{Hf}$ isotopic compositions and the trace element data, we should be able to better constrain both the number and the origin of the components involved in the genesis of the lavas. Figures $4 \mathrm{a}, \mathrm{b}$ and c provide crucial information about the mixing processes because the relationship between $\mathrm{Hf}$ isotopes and trace element ratios with Hf as denominator will define straight lines only if a binary mixture is responsible of the isotopic change. Mixing of magmas should produce linear arrays in diagrams in which trace element ratios with $\mathrm{Hf}$ as denominator are plotted versus the Hf isotopic ratio (Langmuir et al. 1978). In contrast, if mixing occurs in the source before the melting event and if the two elements have different partition coefficients during melting, the data will scatter in the same diagrams. Ratios of elements with the same incompatibility as Hf will define straight lines in the case of binary source mixing while elements with contrasting partitioning behavior will scatter around the mixing array. This is observed in Figure 4 where Sm/Hf defines straight lines when plotted against $\varepsilon_{\mathrm{Hf}}$ (Figure $4 \mathrm{a}$ ) while $\mathrm{Pb} / \mathrm{Hf}$ and $\mathrm{Sr} / \mathrm{Hf}$ show some scatter (Figs $4 \mathrm{~b}$ and $4 \mathrm{c})$. These relationships favor mixing of sources prior to melting.

Using trace element versus isotope relationships, the number of end-members involved in lava genesis can be evaluated. In Figure $4 \mathrm{a}$ where $\mathrm{Sm} / \mathrm{Hf}$ is plotted as a function of $\mathrm{Hf}$ isotopic composition, the northern, southern and Batan lavas are distributed along three distinct linear arrays. This distribution provides constraints on the contamination processes occurring under the arc: each section of arc (the northern part, the southern part and Batan Island) appears to result from a simple binary mixture of two end-members.

In order to investigate the nature and origin of the mixing processes occurring in Luzon and provide explanations to the unusual Hf isotopic compositions of the Luzon arc lavas, information about the composition of the subducted materials appears critical.

\section{C-Composition of the South China Sea oceanic crust and sediments.}

The basaltic crust of the South China Sea has never been sampled by drilling or dredging. Tu et al. (1992) reported geochemical analyses of basalts from the region, but these samples are from oceanic island that erupted on the seafloor and cannot be taken as representative of the oceanic crust. The South China seafloor is covered by a $1500-3000 \mathrm{~m}$ thick sedimentary pile 
(Hayes and Lewis 1984; Jinmin 1994) that was drilled during ODP Leg 184 in 1999 (location shown on Fig. 1). Its lithological composition corresponds to a simple combination of clays derived from the Chinese continental platform and calcareous nannofossil oozes (Prell et al. 1999). $\varepsilon_{\mathrm{Nd}}$ measured on the terrigenous-hemipelagic clay fraction range from -7.7 to -13.3 (Clift et al. 2002; Li et al. 2003). However, the calcareous fraction, which represents $10 \%$ to $60 \%$ of the sedimentary material, was not analyzed and the bulk composition of the sediment is difficult to evaluate.

Geochemical data representing the uppermost meters of the sedimentary pile are available for piston-cores sampled along the subduction trench (Figure 1) (Chen et al. 1990; McDermott et al. 1993). In the northern part of the arc, their $\varepsilon_{\mathrm{Nd}}$ values vary between -8 and -12 (Chen et al. 1990; McDermott et al. 1993) and are similar to the range reported for the clay fraction of the ODP Leg 184 samples. In the central part of the South China Sea, which is located farther away from the Chinese continental input, the $\mathrm{Nd}$ isotopic compositions are more radiogenic with an $\varepsilon_{\mathrm{Nd}}$ value of -0.4 (McDermott et al. 1993). Unfortunately, no Hf isotopic compositions were measured on any of the South China Sea sediments.

Fourcade et al. (1994) suggested that the sediments currently on the sea floor in front of the Luzon arc are not necessarily identical to the sediments involved in the source of the Luzon arc lavas because the $\mathrm{Nd} / \mathrm{Sr}$ ratio of the sedimentary material inferred to have contaminated the source differs from that of the presently subducting sediments. These authors suggest that the sedimentary material in the source was pelagic rather than the lithogenous-hemipelagic clay and calcareous ooze mixture currently in the sedimentary pile overlying the South China Sea basaltic crust.

\section{Constraints on the mixing processes provided by $\mathrm{Hf}$ and $\mathrm{Nd}$ isotopes}

Because Hf isotopic compositions are not available for the subducted material, and because the sediments present today on top of the South China Sea oceanic crust might not be representative of those in the Luzon arc source, another approach has to be used to constrain the nature and origin of the components in the sources of the Luzon arc lavas. We therefore choose to use the relationships between trace element ratios and $\mathrm{Nd}$ and $\mathrm{Hf}$ isotopic compositions to constrain the form and position of the mixing arrays in $\varepsilon_{\mathrm{Hf}} \varepsilon_{\mathrm{Nd}}$ isotope space. While $\varepsilon_{\mathrm{Nd}}$ and $\varepsilon_{\mathrm{Hf}}$ values are identical in arc volcanics and in their source, the trace-element ratios are often modified during partial melting and/or fractional crystallisation. It has been 
shown that $\mathrm{Nd}$ is more incompatible than $\mathrm{Hf}$ not only during the mantle melting that produces MORB and OIB (Hofmann 1988; Sun and McDonough 1989; Chauvel and Blichert-Toft 2001) but also during the formation of island arc basalts (Pearce et al. 1999). The Nd/Hf ratio measured on lavas is not necessarily the source ratio. In contrast, Sm has been demonstrated to have about the same compatibility as Hf during formation of the vast majority of magmas, and the Sm/Hf ratio appears unchanged during magma formation (Hofmann 1988; Sun and McDonough 1989; Blichert-Toft and Albarède 1999; Blichert-Toft et al. 1999b; Chauvel and Blichert-Toft 2001). It can therefore be used, together with $\varepsilon_{\mathrm{Nd}}$ and $\varepsilon_{\mathrm{Hf}}$ values, to evaluate source compositions.

In Fig. 4a, each of the three Luzon arc groups (northern islands, southern islands and Batan island) defines a linear relationship between $\mathrm{Sm} / \mathrm{Hf}$ and $\varepsilon_{\mathrm{Hf}}$. suggesting that each group could result from simple mixing of only two sources. When $\mathrm{Hf} / \mathrm{Nd}$ is plotted as a function of $\varepsilon_{\mathrm{Nd}}$, as in Figure 6, the situation is more complicated. The simple mixing relation is perturbed because $\mathrm{Nd}$ is slightly more incompatible than $\mathrm{Hf}$ (or $\mathrm{Sm}$ ) during partial melting. $\mathrm{Hf} / \mathrm{Sm}$ is therefore a better proxy to the source compositions than $\mathrm{Hf} / \mathrm{Nd}$ and it is for this reason that we used it in Figure 7. Theoretically, the mixing arrays in Figure 7 are not straight lines but hyperbola but their curvature is very limited if the $\mathrm{Sm} / \mathrm{Nd}$ ratios of the end-members are similar. Figure 8 shows that for each of the three island groups, $\mathrm{Sm} / \mathrm{Nd}$ varies by a factor of less than 2.

In Figure 7, the correlation coefficients are not as good as for the $\mathrm{Sm} / \mathrm{Hf}$ versus $\varepsilon_{\mathrm{Hf}}$ relationship (Figure 4a) (0.81, 0.61 and 0.84 instead of $0.96,0.91$ and 0.72$)$, probably because of scatter that we attribute to changes of $\mathrm{Sm} / \mathrm{Nd}$ ratios during partial melting. However, the mixing arrays can be approximated as straight lines and we can use them to characterize the source compositions of the lavas.

The equations defining the three linear arrays in Figures 4a and 7 are given in the Figures and can be combined to derive the relationship between ${ }^{176} \mathrm{Hf} /{ }^{177} \mathrm{Hf}$ and ${ }^{143} \mathrm{Nd} /{ }^{144} \mathrm{Nd}$ in Figure 9. For each island group, a mixing hyperbola can be calculated :

$$
\begin{aligned}
& \varepsilon_{H f}=-\left(\frac{1}{0.0032 \cdot \varepsilon_{N d}+0.083}\right)+21.72 \text { for the Northern islands (1) } \\
& \varepsilon_{H f}=-\left(\frac{1}{0.0088 \cdot \varepsilon_{N d}+0.124}\right)+21.60 \text { for the Southern islands (2) }
\end{aligned}
$$


and $\varepsilon_{H f}=\left(\frac{1}{-0.0054 \cdot \varepsilon_{N d}+0.034}\right)-19.85$ for Batan volcanics (3)

Figure 9 shows clearly that the arrays for the northern and southern islands are similar while the curvature of the Batan island array is in the opposite direction. Because each array in Fig. 9 is a hyperbola, the asymptotic values can be used to constrain the isotopic compositions of the end-members. Reference to Figure 9 shows that the radiogenic end-members of the northern and southern islands have $\varepsilon_{\mathrm{Hf}}$ values no higher than +21.7 and +21.6 , respectively (Fig. 9), while for Batan Island the $\varepsilon_{\mathrm{Nd}}$ value of the radiogenic end-member should be lower than +6.3 . The non-radiogenic end-members of the northern and southern islands should have $\varepsilon_{\mathrm{Nd}}$ values higher than -25.9 and -14.1, respectively, while for Batan Island, the non-radiogenic end-member should have an $\varepsilon_{\mathrm{Hf}}$ value higher than -19.9 (Fig. 9).

\section{E. Potential origins for the radiogenic end-members}

In Figure 9, the mixing arrays of the northern and southern islands are seen to pass through the MORB field, which suggests that the radiogenic end-members of these two groups could be normal MORB-like mantle. However, these two radiogenic end-members seem to have different $\varepsilon_{\mathrm{Hf}}$ ratios because the two mixing hyperbolas do not intersect in the MORB field. Using Figure $4 \mathrm{a}$, the $\varepsilon_{\mathrm{Hf}}$ values of the radiogenic end-members for the northern and southern islands can be shown to differ by about 3 to 5 epsilon units because the $\mathrm{Sm} / \mathrm{Hf}$ ratio of the depleted mantle source should be within known limits. It cannot be lower than about 0.4 , the extremely low value reported by Murton et al. (1992) for Western Pacific boninites and is most probably no higher than normal depleted MORB mantle.

The northern and southern islands of the Luzon arc therefore seem to have slightly different mantle sources, the southern group of islands having a depleted mantle component with a more radiogenic $\mathrm{Hf}$ isotopic composition than the northern group.

For Batan Island, the situation is different because the mixing curve does not pass through the MORB field and the hyperbola has an $\varepsilon_{\mathrm{Nd}}$ asymptotic value of +6.3 (Fig. 9). In addition, the correlation between $\varepsilon_{\mathrm{Hf}}$ and $\mathrm{Sm} / \mathrm{Hf}$ for the Batan volcanics indicates that the radiogenic endmember has a Sm/Hf ratio higher than that of MORB (Figure 4a). These two constraints suggest that the radiogenic end-member for Batan Island is not the depleted mantle source of 
normal MORB. Chen et al. (1990) suggested that the source could be enriched mantle, like the source of some oceanic island basalts but McDermott et al. (1993) argued that $\mathrm{Pb}$ isotopes provide no evidence for the involvement of such an enriched source. As an alternative, we suggest that the radiogenic end-member of the Batan lavas could be a depleted mantle source already contaminated by subducted materials. The relatively low $\varepsilon_{\mathrm{Nd}}(\approx+6)$ and the elevated $\mathrm{Sm} / \mathrm{Hf}$ ratio of this modified mantle suggest that the component added to the depleted mantle was at least partly derived from sedimentary materials and not only from a basaltic crust with MORB characteristics.

\section{$F$. The unradiogenic end-members}

The unradiogenic end-members of the three Luzon groups are inferred to represent fluids or siliceous melts derived from the subducted sediments and from the basaltic crust. The compositions of these components lie on the three mixing hyperbolas but their exact locations are not well constrained. Little isotopic information on the South China Sea sediments is available in the literature, and the only published data were reported by Chen et al. (1990), McDermott et al. (1993), Clift et al. (2002) and Li et al. (2003) who measured the $\varepsilon_{\mathrm{Nd}}$ values of terrigenous clays and reported values ranging from -8 to -13 . They did not measure the $\varepsilon_{\mathrm{Nd}}$ values of the nannofossil oozes that are mixed with the terrigenous-hemipelagic clays and represent 10 to $60 \%$ of the sedimentary pile (Clift et al. 2002; Li et al. 2003). Palmer and Elderfield (1985) and Palmer and Elderfield (1986) measured the Nd isotopic composition of similar oozes in the Atlantic ocean and demonstrated that these samples register the composition of seawater. Since seawater in the Western Pacific and South China Sea has $\varepsilon_{\mathrm{Nd}}$ values of -6 to -4 (Piepgras and Jacobsen 1988; Albarède and Goldstein 1992; Li et al. 2003), we can assume that the nannofossil oozes should have the same $\mathrm{Nd}$ isotopic composition. The $\varepsilon_{\mathrm{Nd}}$ value of the South China Sea nannofossil oozes should therefore be significantly less negative than the $\varepsilon_{\mathrm{Nd}}$ value of -8 to -13 reported for the clay fraction, and the average $\mathrm{Nd}$ isotopic composition of the sediment pile should be at least as radiogenic as the clay fraction. On the other hand, fluids derived from the subducted basaltic crust should have a radiogenic $\mathrm{Nd}$ isotopic composition close to that of MORB, with an $\varepsilon_{\mathrm{Nd}}$ of +10 . As a consequence, the range of isotopic composition reported for South China Sea clays $\left(\varepsilon_{\mathrm{Nd}}=-8\right.$ to -13$)$ should represent the minimum $\varepsilon_{\mathrm{Nd}}$ values for the unradiogenic end-members since all other subducted materials, calcareous nannofossil oozes and basaltic crust, have more positive $\varepsilon_{\mathrm{Nd}}$ values. This 
range is reported in Figure 9 and should be considered as the lowest possible value for the subducted material.

Fourcade et al. (1994) suggested that the Sr-Nd isotopic compositions of the Luzon lavas required a contribution from pelagic sediments with compositions different from those of sediments now in the ocean basin. In other areas such sediments have $\varepsilon_{\mathrm{Nd}}$ values of about -2 to -8 (Ben Othman et al. 1989; Godfrey et al. 1997), values that are higher than the $\varepsilon_{\mathrm{Nd}}$ of -8 to 13 of present day South China clays.

In summary, it appears that the Nd isotopic ratios reported for clays from the South China Sea represent minimum values for the material recycled into the subduction zone and involved in the source of lavas under the Luzon arc. The Hf isotopic composition of the subducted material remains unknown since no local sediments were analyzed.

The three mixing arrays shown on Figure 9 can be used to constrain the compositions of the enriched component that mixed with peridotite in the mantle wedge and by consequence its possible origin.

The mixing hyperbola defined by the northern islands place strong constraints on the composition of the enriched end-member since the lavas with the lowest $\varepsilon_{\mathrm{Nd}}$ values (-6.7) are located close to the field of South China Sea sediments in Figure 9 and the curvature of the mixing array is not strong in the portion covered by the South China Sea sediments. The bold portion of the mixing hyperbola in Figure 9 illustrates possible combinations of $\varepsilon_{\mathrm{Hf}}$ and $\varepsilon_{\mathrm{Nd}}$ for the enriched end-member: $\varepsilon_{\mathrm{Hf}}$ from -2.4 to +5.5 and $\varepsilon_{\mathrm{Nd}}$ from -13 to -7 . The unradiogenic endmember of the northern islands therefore plots above the Hf-Nd terrestrial array of Vervoort et al. (1999) with a composition similar to values reported for Fe-Mn crusts and nodules (see Figure 9). However, two factors argue against involvement of such sediments in the source of the lavas:

- even though Fe-Mn crusts have been reported by Li et al. (2003) in the central part of the South China Sea, the monotonous, 900m thick sedimentary pile drilled during Leg ODP 184 does not contain any ferromanganese crust and such deposits cannot constitute a significant component of the South China Sea sedimentary cover.

- Fe-Mn crusts and nodules have high Nd/Hf ratios ranging from 14 to 35 (Ben Othman et al. 1989; Godfrey et al. 1997), ratios that are incompatible with the $\mathrm{Nd} / \mathrm{Hf}$ ratios of 7 to 11 calculated for the unradiogenic end-member using the mixing relationships. 
The only other sediments with equivalent $\mathrm{Nd}$ and $\mathrm{Hf}$ isotopes are the 7 pelagic clays analyzed by White et al. (1986), Ben Othman et al. (1989) and Godfrey et al. (1997) and Marini et al's. (2003) recent analyses of Pacific pelagic sediments. These materials, which consist of clay minerals (including authigenic clays) and siliceous microfossils, have $\mathrm{Hf}-\mathrm{Nd}$ isotopic compositions similar to those of Fe-Mn crusts and nodules and plot above the Hf-Nd terrestrial array (see Fig. 9). These pelagic clays also have $\mathrm{Nd} / \mathrm{Hf}$ ratios ranging between 7 and 14, the values required for the unradiogenic end-member of the Northern Luzon islands. In addition, involvement of pelagic materials would help explain the negative $\mathrm{Ce}$ anomalies that characterize lavas from the northern islands (Fig. 5) since such anomalies are typical of biogenous and hydrogenous pelagic sediments (Shimizu and Masuda 1977; Elderfield and Greaves 1981; Elderfield et al. 1981; Palmer 1985; Palmer and Elderfield 1986; Ben Othman et al. 1989; Toyoda et al. 1990; Lin 1992). The involvement of such pelagic sediments in the source of the northern islands could therefore account for both the $\mathrm{Hf}-\mathrm{Nd}$ isotopic compositions and the trace element characteristics of the lavas.

For the southern islands, the composition of the unradiogenic end-member is more difficult to constrain because the mixing hyperbola shown in Figure 9 is almost vertical when it approaches the $\varepsilon_{\mathrm{Nd}}$ values of South China Sea sediments. Isotopic compositions as diverse as those of Fe-Mn crusts, pelagic sediments and lithogenous sediments could all, in principle, explain the mixing array. However, if we combine the isotopic constraints with those from the trace elements, we can restrict the type of subducted material that was involved in the source of the southern islands. Because of the curvature of the mixing array in Figure 9, the position in the array of the unradiogenic end-member has strong implications for its $\mathrm{Nd}$ and $\mathrm{Hf}$ contents. As for the northern islands of the arc, the enriched end-member could lie above the "terrestrial array" and be located in the field of Fe-Mn crust and nodules in Fig. 9. In this case its $\mathrm{Nd} / \mathrm{Hf}$ ratio would be low, at about 12. As argued above for the northern island group, the rarity of Fe-Mn crust in the South China Sea and the very high $\mathrm{Nd} / \mathrm{Hf}$ ratios of what exists argue against their involvement in the arc source. The relatively low $\mathrm{Nd} / \mathrm{Hf}$ calculated for the unradiogenic end-member, together with the systematic negative Ce anomaly of the southern lavas (see Figure 5) point to the involvement of pelagic sediments.

Alternatively, the enriched end-member could belong to the terrestrial array and have an elevated $\mathrm{Nd} / \mathrm{Hf}$ ratio of about 25 to 30 . However, this is much higher than values reported for sediments with similar Hf and Nd isotopic compositions (see for example, White et al. (1986), 
Ben Othman et al. (1989), McLennan et al. (1990), Pearce et al. (1999) and Vervoort et al. (1999) who report Nd/Hf values between 0.7 to 14). Dehydration of subducted sediments could produce aqueous fluids with high $\mathrm{Nd} / \mathrm{Hf}$ ratios because $\mathrm{Hf}$ is particularly insoluble in aqueous liquids compared to $\mathrm{Nd}$ (Stalder et al. 1998). However such fluids would also fractionate other element ratios, in particular the U/Th ratio (Turner et al. 1996; Hawkesworth et al. 1997a; Hawkesworth et al. 1997b). Fig. 10 shows clearly not only that the Luzon arc lavas do not have elevated U/Th ratios but also that for each island group a trend of decreasing $\mathrm{U} / \mathrm{Th}$ ratios is associated with a decrease of $\varepsilon_{\mathrm{Hf}}$ values. This is the opposite of what would be expected for fluid produced by dehydration of subducted materials. It can be concluded that fluids produced by dehydration of either subducted sediments or the basaltic oceanic crust are unlikely candidates for the unradiogenic end-member of the southern islands mixing array. Elevated $\mathrm{Nd} / \mathrm{Hf}$ ratios can also result from rutile fractionation during melting or dehydration of sediments since experimental studies show that $\mathrm{Hf}$ is much more compatible than $\mathrm{Nd}$ in rutile compared with fluids or silicate melts (Brenan et al. 1994; Stalder et al. 1998; Foley et al. 2000). The presence of residual rutile beneath the Mariana and Aleutian arcs has already been proposed by Elliott et al. (1997) and Class et al. (2000) to explain the relationship between $\mathrm{Nb}$ and $\mathrm{Th}$ in those arcs; they did not, however, consider the effect of its fractionation on the $\mathrm{Nd} / \mathrm{Hf}$ ratio. If rutile fractionates during melting of a sedimentary component, the resulting liquid should have elevated $\mathrm{Th} / \mathrm{Nb}, \mathrm{La} / \mathrm{Nb}$ and $\mathrm{Nd} / \mathrm{Hf}$ associated with low $\varepsilon_{\mathrm{Hf}}$. This is exactly what is seen in Figure 11 where, in samples from the northern and southern Luzon islands, a decrease in $\mathrm{Hf}$ isotopic ratios correlates with an increase in $\mathrm{Th} / \mathrm{Nb}$ and $\mathrm{La} / \mathrm{Nb}$ ratios. The increase of $\mathrm{Th} / \mathrm{Nb}$ and $\mathrm{La} / \mathrm{Nb}$ ratios is a measure of the magnitude of the $\mathrm{Nb}-\mathrm{Ta}$ anomalies in the Luzon lavas trace element patterns (Figure 3) which become deeper as the concentrations of the most incompatible elements increase. Such behaviour cannot be attributed to the involvement of aqueous fluids with extremely low $\mathrm{Nb}$ contents because, as mentioned above and shown in Figure 10, the variations of U/Th argue against such an interpretation. Neither can the large negative $\mathrm{Nb}$ anomalies that characterize the Luzon lavas be due to the involvement of Nb-poor sedimentary materials because most Luzon arc lavas have $\mathrm{Th} / \mathrm{Nb}$ and $\mathrm{La} / \mathrm{Nb}$ ratios higher than common sediments (Fig. 11). Consequently, the $\mathrm{Nb}$ anomalies are most likely to be due to preferential retention of $\mathrm{Nb}$ in a residual HFSE-rich phase like rutile. The retention of such a phase during partial melting could therefore explain the high $\mathrm{Nd} / \mathrm{Hf}$ ratios inferred for the unradiogenic end-member. However, residual rutile cannot explain the systematic negative Ce anomalies found in the southern Luzon volcanics 
(Figure 5) and this leads us to consider that the most likely candidate for the enriched endmember is pelagic sediment as for the northern islands..

For Batan island, the situation is different because in Figure 9 the mixing array is curved in the opposite direction to that of the other islands. The unradiogenic end-member of the mixing array is constrained to have an $\varepsilon_{\mathrm{Nd}}$ value between -13 and -5 and an $\varepsilon_{\mathrm{Hf}}$ of -10 to -3 (Fig. 9). It cannot have had a negative Ce anomaly (see Figure 5) and its U/Th ratio must have been lower than 0.15 (Figure 10). Unlike the cases considered previously, the $\mathrm{Nd} / \mathrm{Hf}$ ratio of this end-member cannot be calculated using the curvature of the hyperbola because the nature and composition of the radiogenic component of Batan island is not well constrained. All we know is that it is not ordinary depleted mantle, as discussed earlier. In Figure 9, the Batan Island mixing hyperbola lies below the field of Fe-Mn crust and nodules but passes through the field of lithogenous-hemipelagic clays. It follows that lithogenous-hemipelagic clays similar to those drilled in the South China Sea during ODP leg 184 could contribute to the source of Batan lavas.

In summary, our new Hf isotopic measurements, when combined with other isotopic and trace element data, provide useful constraints on the nature of the sources involved in the genesis of the Luzon arc volcanics. The relationship between $\mathrm{Sm} / \mathrm{Hf}$ and $\mathrm{Hf}$ isotopic compositions (Fig. 4a) demonstrates that three different geographic groups can be distinguished along the Luzon arc. For each group, the REE and Hf characteristics of the lavas results from simple mixing between only two end-members. The mixing arrays that characterize the northern and southern islands indicate that the sources located under the islands consist of MORB-like depleted mantle contaminated by liquids derived from sedimentary material with radiogenic $\mathrm{Hf}$ isotopes, negative $\mathrm{Ce}$ anomalies, elevated $\mathrm{Th} / \mathrm{U}$ and very low $\mathrm{Ce} / \mathrm{Pb}$ ratios. These characteristics are best attributed to pelagic clays. For Batan Island, the situation is slightly different since mixing occurs between contaminated or metasomatised depleted mantle and an unradiogenic component derived from lithogenous-hemipelagic clays.

Our new Hf isotopic results reinforce the conclusions reached by previous workers about the control of lava composition by the type and amount of subducted sediment (Defant et al. 1989; Defant et al. 1990; McDermott et al. 1993; Fourcade et al. 1994). In particular, the correlation between the amplitude of negative Ce anomalies and $\mathrm{Hf}$ isotope ratios is a strong argument in 
favour of an authigenic origin for the sediment in the source of the lavas. Such sediments differ from the lithogenous-hemipelagic clays and calcareous nannofossil oozes that are presently being subducted at the trench but they are consistent with the suggestion made by Fourcade et al. (1994) to explain the Sr-Nd array. In addition, the relationships between REE and $\mathrm{Hf}$, and in particular between $\mathrm{Sm} / \mathrm{Hf}$ and the $\mathrm{Hf}$ isotopic ratio (Fig. 4a), show that fluid from subducted basaltic crust does not represent a discrete end-member. Although the subducted basaltic crust no doubt contributes to the REE and HFSE budget of the Luzon source, this contribution is always combined, and probably overwhelmed by the sedimentary contribution. Indeed, the significantly negative $\varepsilon_{\mathrm{Nd}}$ values of the three identified unradiogenic end-members of the mixing arrays imply that fluids liberated by the basaltic crust cannot play a major role in the $\mathrm{Hf}$ and $\mathrm{Nd}$ isotopic budget of the Luzon volcanics. Most of the REE and HFSE that is transported from the slab into the source of the arc lavas originates from fluids or silicate melts derived from subducted sediments.

\section{G- How does Luzon compare with other oceanic island arcs?}

The Lesser Antilles and Sunda-Banda arcs share with the Luzon arc a large range of $\varepsilon_{\mathrm{Nd}}$ values, from compositions similar to those of MORB to very non-radiogenic values (Fig. 2). However, in $\varepsilon_{\mathrm{Nd}}$ vs $\varepsilon_{\mathrm{Hf}}$ space (Fig. 2) data from the three arcs have different slopes. The Luzon arc is characterized by high $\mathrm{Hf}$ isotope ratios and the Lesser Antilles arc has the lowest $\varepsilon_{\mathrm{Nd}}$ values. The Sunda-Banda arc lies in an intermediate position and is characterized by two fields, the most radiogenic having $\mathrm{Nd}$ and $\mathrm{Hf}$ isotopes like the Luzon volcanics and the least radiogenic being similar to the Lesser Antilles (Figure 2).

We attribute the difference between the Lesser Antilles, Sunda-Banda and Luzon to differences in the type of sediments involved in the source of the lavas. The subduction of terrigenous sediments from the Guiana craton beneath the Lesser Antilles explains the Sr-Nd isotopes of these lavas (White et al. 1985; White and Dupré 1986) and can also account for their low $\varepsilon_{\mathrm{Hf}}$ values. In the case of the Luzon arc, we attribute the radiogenic Hf isotopic composition to a contribution of pelagic sediments. Finally, in the Sunda-Banda arc, the Hf isotopic compositions indicate that different types of sediments contribute to the source. Pelagic sediments could be involved in the source of lavas with radiogenic Hf isotopic compositions whereas terrigenous-hemipelagic sediments could be present in the source of 
lavas with low $\varepsilon_{\mathrm{Hf}}$ and $\varepsilon_{\mathrm{Nd}}$. Both types of sediments have been recognized in the sedimentary pile present in front of the Sunda-Banda trench. Vroon et al. (1995) reported that terrigenous sediments from the Australian continent were subducted at the Banda trench and Plank and Langmuir (1998) have identified pelagic clays and terrigenous materials at DSDP Sites 211 and 261 and at ODP Site 765 in front of the Java-Sunda trench. Pelagic sediments dominate in the central part of the arc, on the crust subducting beneath Java and Bali, but the proportion of terrigenous sediments from Australia increases to the est in the region of Banda (Vroon et al. 1995).

\section{Summary and conclusions}

In Hf-Nd isotopic space, data from the Luzon arc form a subhorizontal trend distinct from those of the other intra-oceanic arcs: especially at low $\mathrm{Nd}$ isotope ratios, the $\mathrm{Hf}$ isotopic compositions of the Luzon lavas are unusually radiogenic. The only exception is Batan Island where the Hf-Nd isotopic correlation is more normal and similar to that of the Lesser Antilles and Banda arcs. On the basis of Nd-Hf isotopes and trace element data, three geographical groups can be distinguished; for each group the data can be explained in terms of simple binary mixing between two source end-members. The presence of authigenic pelagic clays is suggested in the source region under both northern and southern Luzon islands while more usual lithogenous-hemipelagic clays would explain the enriched end-member under Batan Island..

More generally, the correlation between $\mathrm{Nd}$ and $\mathrm{Hf}$ isotopic compositions in arc lavas seems to be controlled by the nature of the sediments involved in the source. While in Luzon pelagic sediments explain best the subhorizontal isotopic array, in other arcs such as the Lesser Antilles and the Sunda-Banda arc, the Nd-Hf isotopic array is controlled by terrigenous sediments from a continental source

Acknowledgements: This work benefited of valuable help from Francine Keller in the clean lab and on the ICP-MS and of Janne Blichert-Toft and Philippe Telouk while using the Plasma 54 in Lyon. Discussions with Terry Plank, Nicholas Arndt and Mireille Polvé contributed to major improvements in the manuscript. Very careful and pertinent reviews by an anonymous reviewer, Chris Hawkesworth, Julian Pearce, Alex Halliday and Al Hofmann helped us 
produce a more thorough and balanced interpretation of our data with respect to earlier versions of the paper. This work was financial supported by CNRS through the Dyeti program. 


\section{Figure Captions}

Figure 1 Location map of the Luzon arc. Black dots indicate the locations of the studied volcanic islands in the northern part of the arc (segments 1,2 and 3 from Defant et al. (1989 and Defant et al. (1990)). Volcanoes in the southern part of the arc (for example segment 4, which includes Mt Pinatubo and Taal) have been omitted for clarity as they are not studied here. Also shown are the locations of the Lamont-Doherty sediment cores analysed by Chen et al. (1990 and McDermott et al. (1993) and the ODP sites 1144 to 1148 (Leg 184) where the clays analysed by Clift et al. (2002) and Li et al. (2003) were sampled.

Figure $2 \varepsilon_{\mathrm{Hf}} v s . \varepsilon_{\mathrm{Nd}}$ diagram showing data for the Luzon arc together with the fields of the other oceanic arcs (data from White and Patchett (1984), Pearce et al. (1999) and Woodhead et al. (2001). The "Depleted arcs" term is used to group the Marianas, Izu, New Britain, Aleutians and Kermadec arcs which have isotopic compositions close to MORB. Fields for MORB and OIB were drawn using literature data (Patchett and Tatsumoto 1980; Patchett 1983; Stille et al. 1983; Stille et al. 1986; Salters and Hart 1991; Chauvel et al. 1992; Salters 1996; Salters and White 1998; Blichert-Toft and Albarède 1999; Blichert-Toft et al. 1999a; Chauvel and Blichert-Toft 2001).

Figure 3 Trace element patterns of the Luzon arc lavas normalized to the primitive mantle values of Hofmann (1988).

Figure 4 (a) Sm/Hf $v s . \varepsilon_{\mathrm{Hf}}$ diagram of the Luzon arc lavas. On the basis of relations between $\mathrm{Sm} / \mathrm{Hf}$ and the $\varepsilon_{\mathrm{Hf}}$ ratios, three distinct groups can be identified in the Luzon arc: the northern group, the southern group and Batan Island. Babuyan Island is located at the boundary between the northern and southern groups. One sample of this island ( $\mathrm{Bb} 39)$ is included in the southern group but another sample, $\mathrm{Bb} 20$, has a composition intermediate between the two groups. (b) and (c) $\mathrm{Pb} / \mathrm{Hf}$ and $\mathrm{Sr} / \mathrm{Hf} v s . \varepsilon_{\mathrm{Hf}}$ diagram of the Luzon arc lavas showing the same three Luzon groups. The primitive mantle and MORB values in this and other diagrams are from Hofmann (1988).

Figure $5 \mathrm{Ce} / \mathrm{Ce}^{*} v s . \varepsilon_{\mathrm{Hf}}$ diagram for the Luzon arc lavas. Ce anomalies, denoted $\mathrm{Ce} / \mathrm{Ce}{ }^{*}$ are defined as the ratio of $\mathrm{Ce}$ content normalized to primitive mantle $\left(\mathrm{Ce}_{\mathrm{N}}\right)$ to $\mathrm{Ce}^{*}{ }_{\mathrm{N}}$ calculated as 
the average of $\mathrm{La}_{\mathrm{N}}$ and $\mathrm{Nd}_{\mathrm{N}}$ values. The northern and southern groups have negative $\mathrm{Ce}$ anomalies whose magnitude correlates with their $\varepsilon_{\mathrm{Hf}}$ ratios. These anomalies are comparable to those in the Marianas arc lavas (White and Patchett 1984; Pearce et al. 1999; Woodhead et al. 2001). Batan samples do not have significant Ce anomalies.

Figure $6 \mathrm{Hf} / \mathrm{Nd} v s . \varepsilon_{\mathrm{Nd}}$ diagram for the Luzon arc lavas. The data scatter around linear arrays because of the combined effects of mixing and melting which both change the $\mathrm{Hf} / \mathrm{Nd}$ ratio (see text for further explanation). The range of the present day South China Sea sediments has been drawn using the data of Chen et al. (1990), McDermott et al. (1993), Clift et al. (2002) and Li et al. (2003).

Figure $7 \mathrm{Hf} / \mathrm{Sm} v s . \varepsilon_{\mathrm{Nd}}$ diagram for the Luzon arc lavas. For the northern, southern and Batan lavas the $\mathrm{Hf} / \mathrm{Sm}$ ratios show approximate linear correlations with the $\varepsilon_{\mathrm{Nd}}$ values (see text for discussion). Data sources as in Figure 6.

Figure $8 \mathrm{Sm} / \mathrm{Nd} v s . \varepsilon_{\mathrm{Nd}}$ diagram showing that the $\mathrm{Sm} / \mathrm{Nd}$ ratio of each group of lavas does not change by more than a factor of two. Data source as in Figure 6.

Figure $9 \varepsilon_{\mathrm{Hf}}$ vs. $\varepsilon_{\mathrm{Nd}}$ diagram showing the mixing hyperbolas of the three Luzon lavas groups, together with the oceanic sediments. On each hyperbola, the ranges of the non radiogenic endmembers are indicated by thick strokes. Lithogenous sediment data and Fe-Mn crusts and nodules field are from White et al. (1986), Ben Othman et al. (1989), Godfrey et al. (1997), Albarède et al. (1998), Pearce et al. (1999), Vervoort et al. (1999) and David et al. (2001). The present day South China Sea sediment range is from Chen et al. (1990), McDermott et al. (1993), Clift et al. (2002) and Li et al. (2003). The field for Site 1149 Pacific pelagic sediments is from Marini et al. (2003). These sediments are mixtures of clay minerals, volcanic ash and siliceous nannofossils, and have $\mathrm{Hf}$ and $\mathrm{Nd}$ isotopic compositions similar to those of Fe-Mn crusts and nodules. The "terrestrial array" is from Vervoort et al. (1999) and the MORB field has been drawn using the same references as in Fig. 2.

Figure $10 \mathrm{U} / \mathrm{Th}$ vs. $\varepsilon_{\mathrm{Hf}}$ diagram for Luzon arc lavas. The U/Th ratios of the lavas do not increase as $\varepsilon_{\mathrm{Hf}}$ decreases showing that the non radiogenic components of the source do not have high $\mathrm{U} / \mathrm{Th}$ ratios. 
Figure 11 (a) $\mathrm{Th} / \mathrm{Nb}$ vs. $\varepsilon_{\mathrm{Hf}}$ and (b) La/Nb vs. $\varepsilon_{\mathrm{Hf}}$ diagrams for Luzon arc lavas, together with compositions of lithogenous sediments (McLennan et al. 1990; Pearce et al. 1999; Vervoort et al. 1999) and the average upper continental crust value (McLennan 2001). The increasing $\mathrm{Th} / \mathrm{Nb}$ and $\mathrm{La} / \mathrm{Nb}$ ratios cannot be explained by involvement of HFSE-depleted aqueous fluids because there is no associated increase in U/Th ratios (see Fig. 10). Nor can the involvement of sediments from continental crust explain the data because the northern and southern Luzon lavas have HFSE anomalies that are often bigger than in detrital sediments. Consequently these diagrams suggest that $\mathrm{Nb}$ is retained in the source in a residual HFSE rich mineral such as rutile. 


\section{References}

Albarède F, Goldstein SL (1992) World map of Nd isotopes in sea-floor ferromanganese deposits. Geology 20:761-763

Albarède F, Simonetti A, Vervoort JD, Blichert-Toft J, Abouchami W (1998) A Hf-Nd isotopic correlation in ferromanganese nodules. Geophysical Research Letters 25(20):3895-3898

Barrat JA, Keller F, Amossé J, Taylor RN, Nesbitt RW, Hirata T (1996) Determination of rare earth elements in sixteen silicate reference samples by ICP-MS after Tm addition and ion exchange separation. Geostandards Newsletter 20:133-139

Bau M, Knittel U (1993) Significance of slab-derived partial melts and aqueous fluids for the genesis of tholeiitic and calc-alkaline island-arc basalts: Evidence from Mt. Arayat, Philippines. Chemical Geology 105:233-251

Ben Othman D, White WM, Patchett PJ (1989) The geochemistry of marine sediments, island arc magma genesis, and crust-mantle recycling. Earth and Planetary Science Letters 94:1-21

Blichert-Toft J, Albarède F (1997) The Lu-Hf isotope geochemistry of chondrites and the evolution of the mantle-crust system. Earth and Planetary Science Letters 148:243-258

Blichert-Toft J, Albarède F (1999) Hf isotopic compositions of the Hawaii Scientific Drilling Project core and the source mineralogy of Hawaiian basalts. Geophysical Research Letters 26(7):935-938

Blichert-Toft J, Chauvel C, Albarède F (1997) Separation of Hf and Lu for high-precision isotope analysis of rock samples by magnetic sector-multiple collector ICP-MS. Contributions to Mineralogy and Petrology 127:248-260

Blichert-Toft J, Frey FA, Albarède F (1999a) Hf isotope evidence for pelagic sediments in the source of Hawaiian basalts. Science 285:879-882

Blichert-Toft J, Gleason JD, Télouk P, Albarède F (1999b) The Lu-Hf isotope geochemistry of shergottites and the evolution of the Martian mantle-crust system. Earth and Planetary Science Letters 173:25-39

Brenan JM, Shaw HF, Phinney DL, Ryerson FJ (1994) Rutile-aqueous fluid partitioning of $\mathrm{Nb}$, Ta, Hf, Zr, U and Th: Implications for high field strength element depletions in island-arc basalts. Earth and Planetary Science Letters 128:327-339

Chauvel C, Blichert-Toft J (2001) A hafnium isotope and trace element perspective on melting of the depleted mantle. Earth and Planetary Science Letters 190:137-151 
Chauvel C, Hofmann AW, Vidal P (1992) HIMU-EM: The French Polynesian connection. Earth and Planetary Science Letters 110:99-119

Chen C-H, Shieh Y-N, Lee T, Chen C-H, Mertzman SA (1990) Nd-Sr-O isotopic evidence for source contamination and an unusual mantle component under Luzon Arc. Geochimica et Cosmochimica Acta 54:2473-2483

Class C, Miller DM, Goldstein SL, Langmuir CH (2000) Distinguishing melt and fluid subduction components in Umnak Volcanics, Aleutian Arc. Geochemistry, Geophysics, Geosystems 1:Paper number 1999GC000010

Clift P, Lee JI, Clark MK, Blusztajn J (2002) Erosional response of South China to arc rifting and monsoonal strengthening; a record from the South China Sea. Marine Geology $184: 207-226$

David K, Frank M, O'Nions RK, Belshaw NS, Arden JW (2001) The Hf isotope composition of global seawater and the evolution of Hf isotopes in the deep Pacific Ocean from FeMn crusts. Chemical Geology 178:23-42

Defant MJ, Jacques D, Maury RC, Boer JD, Joron J-L (1989) Geochemistry and tectonic setting of the Luzon arc, Philippines. Geological Society of America Bulletin 101:663672

Defant MJ, Maury RC, Joron J-L, Feigenson MD, Leterrier J, Bellon H, Jacques D, Richard M (1990) The geochemistry and tectonic setting of the northern section of the Luzon arc (the Philippines and Taiwan). Tectonophysics 183:187-205

Eggins SM, Woodhead JD, Kinsley LPJ, Mortimer GE, Sylvester P, McDulloch MT, Hergt JM, Handler MR (1997) A simple method for the precise determination of $\geq 40$ trace elements in geological samples by ICPMS using enriched isotope internal standardisation. Chemical Geology 134:311-326

Elderfield H, Greaves MJ (1981) Negative cerium anomalies in the rare earth element patterns of oceanic ferromanganese nodules. Earth and Planetary Science Letters 55:163-170

Elderfield H, Hawkesworth CJ, Greaves MJ, Calvert SE (1981) Rare earth element geochemistry of oceanic ferromanganese nodules and associated sediments. Geochimica et Cosmochimica Acta 45:513-528

Ellam RM, Hawkesworth CJ (1988) Elemental and isotopic variations in subduction related basalts: Evidence for a three component model. Contributions to Mineralogy and Petrology 98:72-80 
Elliott T, Plank T, Zindler A, White WM, Bourdon B (1997) Element transport from slab to volcanic front at the Mariana arc. Journal of Geophysical Research 102(B7):1499115019

Foley SF, Barth MG, Jenner GA (2000) Rutile/melt partition coefficients for trace elements and an assessment of the influence of rutile on the trace element characteristics of subduction zone magmas. Geochimica et Cosmochimica Acta 64(5):933-938

Fourcade S, Maury RC, Defant MJ, Dermott FM (1994) Mantle metasomatic enrichment versus arc crust contamination in the Philippines: Oxygen isotope study of Batan ultramafic nodules and northern Luzon arc lavas. Chemical Geology 114:199-215

Gill JB (1981) Orogenic andesites and plate tectonics, vol., New York, p 330

Godfrey LV, Lee D-C, Sangrey WF, Halliday AN, Salters VJM, Hein JR, White WM (1997) The Hf isotopic composition of ferromanganese nodules and crusts and hydrothermal manganese deposits: Implications for seawater Hf. Earth and Planetary Science Letters 151:91-105

Govindaraju K (1994) 1994 compilation of working values and sample description for 383 geostandards. Geostandards Newsletters 18(special issue):158

Hall R, Ali JR, Anderson CD, Baker SJ (1995) Origin and motion history of the Philippine Sea Plate. Tectonophysics 251:229-250

Hawkesworth CJ, Gallagher K, Hergt JM, McDermott F (1993a) Mantle and slab contributions in arc magmas. Annual Review of Earth and Planetary Sciences 21:175204

Hawkesworth CJ, Gallagher K, Hergt JM, McDermott F (1993b) Trace element fractionation processes in the generation of island arc basalts. Philosophical Transactions of the Royal Society of London. A 342:179-191

Hawkesworth CJ, Gallagher K, Hergt JM, McDermott F (1994) Destructive plate margin magmatism: Geochemistry and melt generation. Lithos 33:169-188

Hawkesworth CJ, Turner SP, McDermott F, Peate DW, Calsteren PV (1997a) U-Th isotopes in arc magmas: Implications for element transfer from the subducted crust. Science 276:551-555

Hawkesworth CJ, Turner SP, Peate DW, McDermott F, Calsteren PV (1997b) Elemental UTh variations in island arc rocks: Implications for U-series isotopes. Chemical Geology 139:207-221 
Hayes DE, Lewis SD (1984) A geophysical study of the Manila trench, Luzon, Philippines 1. Crustal structure, gravity, and regional tectonic evolution. Journal of Geophysical Research 89(B11):9171-9195

Hofmann AW (1988) Chemical differentiation of the Earth: the relationship between mantle, continental crust, and oceanic crust. Earth and Planetary Science Letters 90:297-314

Hofmann AW, Jochum KP, Seufert M, White WM (1986) Nb and Pb in oceanic basalts: new constraints on mantle evolution. Earth Planet. Sci. Lett. 79:33-45

Hole MJ, Saunders AD, Marriner GF, Tarney J (1984) Subduction of pelagic sediments: Implications for the origin of Ce-anomalous basalts from the Mariana Islands. Journal of the Geological Society of London 141:453-472

Huang C-Y, Wu W-Y, Chang C-P, Tsao S, Yuan PB, Lin C-W, Yuan X-K (1997) Tectonic evolution of accretionary prism in the arc-continent collision terrane of Taiwan. Tectonophysics 281:31-51

Jacques D (1987) Géologie et pétrologie de l'archipel Babuyan et des Monts Tabungon et Cagua, Nord Luzon, Philippines: Implications magmatologiques et géodynamiques. In, vol. Université de Bretagne Occidentale, Brest, p 233

Jenner GA, Longerich HP, Jackson SE, Fryer BJ (1990) ICP-MS - A powerful tool for highprecision trace-element analysis in Earth sciences: Evidence from analysis of selected U.S.G.S. reference samples. Chemical Geology 83:133-148

Jinmin W (1994) Evaluation and models of Cenozoic sedimentation in the South China Sea. Tectonophysics 235:77-98

Langmuir CH, Vocke RD, Hanson GN, Hart SR (1978) A general mixing equation with applications to icelandic basalts. Earth and Planetary Science Letters 37:380-392

Lee T-Y, Lawver LA (1995) Cenozoic plate reconstruction of Southeast Asia. Tectonophysics $251: 85-138$

Li X-H, Wei G, Shao L, Liu Y, Liang X, Jian Z, Sun M, Wang P (2003) Geochemical and Nd isotopic variations in sediments of the South China Sea: A response to Cenozoic tectonism in SE Asia. Earth and Planetary Science Letters 211:207-220

Lin P-N (1992) Trace element and isotopic characteristics of western Pacific pelagic sediments: Implications for the petrogenesis of Mariana Arc magmas. Geochimica et Cosmochimica Acta 56:1641-1654

Marini J-C, Chauvel C, Kelley K, Plank T, Ludden J, Staudigel H (2003) Hf-Nd isotopic budget of subducting oceanic crust and sediments. Geophysical Research Abstracts 5:EAE-A-00622 
Maury RC, Defant MJ, Bellon H, Jacques D, Joron J-L, McDermott F, Vidal P (1998) Temporal geochemical trends in northern Luzon arc lavas (Philippines): Implications on metasomatic processes in the island arc mantle. Bulletin de la Société Géologique de France 169(1):69-80

Maury RC, Defant MJ, Joron J-L (1992) Metasomatism of the sub-arc mantle inferred from trace elements in Philippine xenoliths. Nature 360:661-663

McCulloch MT, Gamble JA (1991) Geochemical and geodynamical constraints on subduction zone magmatism. Earth and Planetary Science Letters 102:358-374

McDermott F, Defant MJ, Hawkesworth CJ, Maury RC, Joron J-L (1993) Isotope and trace element evidence for three component mixing in the genesis of the North Luzon arc lavas (Philippines). Contributions to Mineralogy and Petrology 113:9-23

McLennan SM (2001) Relationships between the trace element composition of sedimentary rocks and upper continental crust. Geochemistry, Geophysics, Geosystems 2:Paper number 2000GC000109

McLennan SM, Taylor SR, Culloch MTM, Maynard JB (1990) Geochemical and Nd-Sr isotopic composition of deep-sea turbidites: crustal evolution and plate tectonic associations. Geochimica et Cosmochimica Acta 54:2015-2050

Murton BJ, Peate DW, Arculus RJ, Pearce JA, Laan SRVd (1992) Trace-element geochemistry of volcanic rocks from Site 786: The Izu-Bonin forearc. Proceedings of the Ocean Drilling Program Scientific Results 125:211-235

Palmer MR (1985) Rare earth elements in foraminifera tests. Earth and Planetary Science Letters 73:285-298

Palmer MR, Elderfield H (1985) Variations in the Nd isotopic composition of foraminifera from Atlantic Ocean sediments. Earth and Planetary Science Letters 73:299-305

Palmer MR, Elderfield H (1986) Rare earth elements and neodymium isotopes in ferromanganese oxide coatings of Cenozoic foraminifera from the Atlantic Ocean. Geochimica et Cosmochimica Acta 50:409-417

Patchett PJ (1983) Hafnium isotope results from mid-ocean ridges and Kerguelen. Lithos $16: 47-51$

Patchett PJ, Tatsumoto M (1980) Hafnium isotope variations in oceanic basalts. Geophysical Research Letters 7(12):1077-1080

Patchett PJ, White WM, Feldmann H, Kielinczuk S, Hofmann AW (1984) Hafnium/rare earth element fractionation in the sedimentary system and crustal recycling into the Earth's mantle. Earth and Planetary Science Letters 69:365-378 
Pearce JA, Kempton PD, Nowell GM, Noble SR (1999) Hf-Nd element and isotope perspective on the nature and provenance of mantle and subduction components in Western Pacific arc-basin systems. Journal of Petrology 40(11):1579-1611

Piepgras DJ, Jacobsen SB (1988) The isotopic composition of neodymium in the North Pacific. Geochimica et Cosmochimica Acta 52:1373-1381

Plank T, Langmuir CH (1993) Tracing trace element from sediment input to volcanic output at subduction zones. Nature 362:739-742

Plank T, Langmuir CH (1998) The chemical composition of subducting sediment and its consequences for the crust and mantle. Chemical Geology 145:325-394

Prell WL, Wang P, Blum P, al. e (1999) Leg 184 Preliminary report-South China Sea. Proceedings of the Ocean Drilling Program:102

Prouteau G, Scaillet B, Pichavant M, Maury RC (1999) Fluid-present melting of ocean crust in subduction zones. Geology 27(12):1111-1114

Pubellier M, Quebral R, Aurelio M, Rangin C (1996) Docking and post-docking tectonics in the southern Philippines. In: Hall R, Blundel D (eds) Tectonic evolution of SE Asia, vol 106. Geological Society of America Special Publication, pp 511-523

Raczek I, Stoll B, Hofmann AW, Jochum KP (2001) High-precision trace element data for the USGS reference materials BCR-1, BCR-2, BHVO-1, BHVO-2, AGV-1, AGV-2, DTS1, DTS-2, GSP-1 and GSP-2 by ID-TIMS and MIC-SSMS. Geostandards Newsletters 25(1):77-86

Richard M, Bellon H, Maury RC, Barrier E, Juang W-S (1986a) Miocene to recent calcalkalic volcanism in eastern Taiwan: K-Ar ages and petrography. Tectonophysics $125: 87-102$

Richard M, Maury RC, Bellon H, Stephan J-F, Boirat J-M, Calderon A (1986b) Geology of Mt. Iraya volcano and Batan island, Northern Philippines. Philippines Bulletin of Volcanology 3:1-27

Sajona FG, Maury RC, Prouteau G, Cotten J, Schiano P, Bellon H, Fontaine L (2000) Slab melt as metasomatic agent in island arc magma mantle sources, Negros and Batan (Philippines). The Island Arc 9:472-486

Salters VJM (1996) The generation of mid-ocean ridge basalts from the $\mathrm{Hf}$ and $\mathrm{Nd}$ isotope perspective. Earth and Planetary Science Letters 141:109-123

Salters VJM, Hart SR (1991) The mantle sources of ocean ridges, islands and arcs: the Hfisotope connection. Earth and Planetary Science Letters 104:364-380 
Salters VJM, White WM (1998) Hf isotope constraints on mantle evolution. Chemical Geology 145:447-460

Saunders AD, Norry MJ, Tarney J (1991) Fluid influence on the trace element compositions of subduction zone magmas. Philosophical Transactions of the Royal Society of London. A 335:377-392

Schiano P, Clocchiatti R, Shimizu N, Maury RC, Jochum KP, Hofmann AW (1995) Hydrous, silica-rich melts in the sub-arc mantle and their relationship with erupted arc lavas. Nature 377:595-600

Shimizu H, Masuda A (1977) Cerium in chert as an indication of marine environment of its formation. Nature 266:346-348

Stalder R, Foley SF, Brey GP, Horn I (1998) Mineral-aqueous fluid partitioning of trace elements at $900-1200^{\circ} \mathrm{C}$ and 3.0-5.7 GPa: New experimental data for garnet, clinopyroxene, and rutile, and implications for mantle metasomatism. Geochimica et Cosmochimica Acta 62(10):1781-1801

Stephan JF, Blanchet R, Rangin C, Pelletier B, Letouzey J, Muller C (1986) Geodynamic evolution of the Taiwan-Luzon-Mindoro belt since the late Eocene. Tectonophysics $125: 245-268$

Stille P, Unruh DM, Tatsumoto M (1983) Pb, Sr, Nd and Hf isotopic evidence of multiple sources for Oahu, Hawaii basalts. Nature 304:25-29

Stille P, Unruh DM, Tatsumoto M (1986) Pb, Sr, Nd, and Hf isotopic constraints on the origin of Hawaiian basalts and evidence for a unique mantle source. Geochimica et Cosmochimica Acta 50:2303-2319

Sun S-S, McDonough WF (1989) Chemical and isotopic systematics of oceanic basalts: Implications for mantle composition and processes. In: Saunders AD, Norry MJ (eds) Magmatism in the Ocean Basins, vol 42. Geological Society Special Publication, London, pp 313-345

Tatsumi Y, Hamilton DL, Nesbitt RW (1986) Chemical characteristics of fluid phase released from a subducted lithosphere and origin of arc magmas: Evidence from high pressure experiments and natural rocks. Journal of Volcanology and Geothermal Research 29:293-309

Taylor SR, McLennan SM (1985) The Continental Crust: Its Composition and Evolution, vol., Boston, Mass., p 312

Taylor SR, McLennan SM (1995) The geochemical evolution of the continental crust. Reviews of Geophysics 33(2):241-265 
Teng LS (1990) Geotectonic evolution of late Cenozoic arc-continent collision in Taiwan. Tectonophysics 183:57-76

Toyoda K, Nakamura Y, Masuda A (1990) Rare earth elements of Pacific pelagic sediments. Geochimica et Cosmochimica Acta 54:1093-1103

Tu K, Flower MFJ, Carlson RW, Xie G, Chen C-Y, Zhang M (1992) Magmatism in the South China Basin 1. Isotopic and trace-element evidence for an endogenous Dupal mantle component. Chemical Geology 97:47-63

Turner SP, Hawkesworth CJ, Calsteren PV, Heath E, Macdonald R, Black S (1996) U-series isotopes and destructive plate margin magma genesis in the Lesser Antilles. Earth and Planetary Science Letters 142:191-207

Vervoort JD, Patchett PJ, Blichert-Toft J, Albarède F (1999) Relationships between Lu-Hf and Sm-Nd isotopic systems in the global sedimentary system. Earth and Planetary Science Letters 168:79-99

Vidal P, Dupuy C, Maury R, Richard M (1989) Mantle metasomatism above subduction zones: Trace-element and radiogenic isotope characteristics of peridotite xenoliths from Batan Island (Philippines). Geology 17:1115-1118

Vroon PZ, Bergen MJV, Klaver GJ, White WM (1995) Strontium, neodymium, and lead isotopic and trace-element signatures of the East Indonesian sediments: provenance and implications for Banda Arc magma genesis. Geochimica et Cosmochimica Acta 59(12):2573-2598

Vroon PZ, Bergen MJV, White WM, Varekamp JC (1993) Sr-Nd-Pb isotope systematics of the Banda arc, Indonesia: combined subduction and assimilation of continental material. Journal of Geophysical Research 98(B12):22349-22366

Vroon PZ, Nowell G, Hoogewerff JA, Bergen MJv (1998) HFSE mobility at the slab-wedge interface: Hafnium-isotope evidence from the east Sunda-Banda arc. Mineralogical Magazine 62A:1617-1618

White WM, Dupré B (1986) Sediment subduction and magma genesis in the Lesser Antilles: isotopic and trace element constraints. Journal of Geophysical Research 91(B6):59275941

White WM, Dupré B, Vidal P (1985) Isotope and trace element geochemistry of sediments from the Barbados Ridge-Demerara Plain region, Atlantic Ocean. Geochimica et Cosmochimica Acta 49:1875-1886 
White WM, Patchett PJ (1984) Hf-Nd-Sr isotopes and incompatible element abundances in island arcs: implications for magma origins and crust-mantle evolution. Earth and Planetary Science Letters 67:167-185

White WM, Patchett PJ, Othman DB (1986) Hf isotope ratios of marine sediments and Mn nodules: evidence for a mantle source of Hf in seawater. Earth and Planetary Science Letters 79:46-54

Woodhead JD (1989) Geochemistry of the Mariana arc (western Pacific): Source composition and processes. Chemical Geology 76:1-24

Woodhead JD, Hergt JM, Davidson JP, Eggins SM (2001) Hafnium isotope evidence for 'conservative' element mobility during subduction zone processes. Earth and Planetary Science Letters 192:331-346 


\begin{tabular}{|c|c|c|c|c|c|c|c|c|c|c|c|c|}
\hline LOCATION & Lutao & Lutao & Lutao & Lanshu & Lanshu & Batan & Batan & Batan & Batan & Batan & Batan & Batan \\
\hline $\begin{array}{l}\text { ROCK TYPE } \\
\text { SAMPLE }\end{array}$ & $\begin{array}{l}\text { Andesite } \\
\text { TW } 36\end{array}$ & $\begin{array}{l}\text { Andesite } \\
\text { TW } 40\end{array}$ & $\begin{array}{l}\text { Andesite } \\
\text { TW } 41\end{array}$ & $\begin{array}{l}\text { Bas. andesite } \\
\text { TW } 31\end{array}$ & $\begin{array}{l}\text { Bas. andesite } \\
\text { TW } 32\end{array}$ & $\begin{array}{l}\text { Bas. andesite } \\
\text { B 3m }\end{array}$ & $\begin{array}{l}\text { Bas. andesite } \\
\text { B10 }\end{array}$ & $\begin{array}{l}\text { Andesite } \\
\text { B42 }\end{array}$ & $\begin{array}{l}\text { Basalte } \\
\text { B80 }\end{array}$ & $\begin{array}{l}\text { Bas. andesite } \\
\text { B88 }\end{array}$ & B15 & B21 \\
\hline K-Ar Age (Ma) & $1.88 \pm 0.28$ & $2.94 \pm 0.15$ & $2.88 \pm 0.15$ & $3.86 \pm 0.2$ & $5.45 \pm 0.27$ & $1480 \pm 50$ years & $2310 \pm$ years & $1.09 \pm 0.08$ & $2.30 \pm 0.35$ & $0.76 \pm 0.04$ & $\begin{array}{l}010 \\
7.19\end{array}$ & $\begin{array}{ll}\text { DLI } \\
9.36\end{array}$ \\
\hline Co (ppm) & 16.9 & 15.5 & 9.75 & 13.6 & 19.1 & 18.6 & 19.2 & 18.2 & 33.3 & 22.1 & 16.3 & 14.6 \\
\hline $\mathrm{Rb}$ & 63.2 & 59.2 & 39.1 & 18.8 & 18.8 & 114 & 107 & 65.9 & 27.7 & 113 & 28 & 25 \\
\hline $\mathrm{Sr}$ & 2622 & 2743 & 600 & 582 & 232 & 641 & 953 & 1366 & 492 & 587 & 292 & 294 \\
\hline Y & 16.4 & 14.0 & 11.7 & 16.0 & 16.2 & 19.6 & 22.2 & 14.5 & 14.4 & 19.6 & 112.2 & 20.0 \\
\hline $\mathrm{Zr}$ & 224 & 203 & 82.0 & 88.4 & 77.3 & 195 & 237 & 143 & 82.3 & 253 & 78 & 72 \\
\hline $\mathrm{Nb}$ & 17.0 & 14.9 & 4.21 & 2.27 & 1.72 & 9.74 & 11.8 & 6.40 & 3.61 & 13.9 & 3.1 & 3.0 \\
\hline Cs & 7.51 & 7.45 & 1.12 & 0.74 & 0.50 & 8.69 & 9.05 & 2.75 & 1.32 & 3.61 & 0.71 & 1.99 \\
\hline $\mathrm{Ba}$ & 1594 & 1524 & 425 & 282 & 186 & 701 & 826 & 549 & 288 & 657 & 326 & 316 \\
\hline La & 169 & 164 & 20.5 & 15.1 & 10.6 & 38.6 & 48.6 & 29.5 & 12.7 & 34.1 & 23.0 & 11.8 \\
\hline $\mathrm{Ce}$ & 282 & 271 & 39.1 & 30.2 & 20.5 & 81.6 & 103 & 61.4 & 29.0 & 80.3 & 22.9 & 23.2 \\
\hline Pr & 25.8 & 24.5 & 4.53 & 3.72 & 2.50 & 9.69 & 12.2 & 7.74 & 3.91 & 10.5 & 5.0 & 2.9 \\
\hline $\mathrm{Nd}$ & 77.6 & 72.4 & 16.2 & 14.5 & 9.65 & 36.2 & 45.8 & 31.6 & 16.9 & 40.6 & 22.9 & 11.8 \\
\hline Sm & 8.73 & 7.75 & 2.89 & 2.84 & 2.13 & 6.17 & 7.96 & 5.81 & 3.51 & 6.81 & 5.38 & 2.64 \\
\hline $\mathrm{Eu}$ & 1.72 & 1.55 & 0.85 & 0.85 & 0.66 & 1.44 & 1.87 & 1.30 & 0.92 & 1.45 & 1.90 & 0.83 \\
\hline $\mathrm{Gd}$ & 4.19 & 3.68 & 2.38 & 2.69 & 2.14 & 4.24 & 5.38 & 4.47 & 2.81 & 4.41 & 7.90 & 2.78 \\
\hline $\mathrm{Tb}$ & 0.52 & 0.46 & 0.34 & 0.41 & 0.35 & 0.58 & 0.69 & 0.49 & 0.41 & 0.59 & 1.22 & 0.46 \\
\hline Dy & 2.61 & 2.25 & 1.90 & 2.54 & 2.25 & 3.13 & 3.62 & 2.54 & 2.44 & 3.26 & 8.65 & 2.95 \\
\hline Ho & 0.52 & 0.43 & 0.40 & 0.55 & 0.51 & 0.65 & 0.72 & 0.50 & 0.50 & 0.66 & 2.35 & 0.67 \\
\hline $\mathrm{Er}$ & 1.55 & 1.33 & 1.16 & 1.60 & 1.60 & 1.92 & 2.08 & 1.23 & 1.42 & 1.93 & 7.39 & 1.99 \\
\hline $\mathrm{Yb}$ & 1.51 & 1.34 & 1.16 & 1.48 & 1.54 & 1.84 & 1.89 & 1.21 & 1.36 & 1.85 & 6.56 & 2.05 \\
\hline Lu & 0.24 & 0.21 & 0.19 & 0.25 & 0.26 & 0.30 & 0.30 & 0.17 & 0.21 & 0.29 & 1.22 & 0.33 \\
\hline $\mathrm{Hf}$ & 5.31 & 4.97 & 2.25 & 2.38 & 2.00 & 4.81 & 5.76 & 3.83 & 2.24 & 6.34 & 2.15 & 1.95 \\
\hline $\mathrm{Ta}$ & 0.93 & 0.85 & 0.27 & 0.14 & 0.11 & 0.57 & 0.66 & 0.35 & 0.20 & 0.78 & 0.19 & 0.17 \\
\hline $\mathrm{Pb}$ & 52.8 & 74.5 & 11.0 & 4.96 & 6.35 & 18.0 & 19.0 & 12.0 & 7.30 & 15.3 & 7.0 & 9.9 \\
\hline Th & 87.4 & 85.2 & 7.48 & 4.82 & 3.29 & 21.5 & 24.4 & 9.07 & 4.94 & 34.3 & 3.9 & 3.7 \\
\hline U & 15.7 & 15.5 & 1.59 & 1.20 & 0.83 & 3.99 & 4.48 & 2.20 & 0.92 & 5.38 & 0.78 & 0.70 \\
\hline $143 \mathrm{Nd} /{ }^{144} \mathrm{Nd}$ & 0.512295 & 0.512316 & 0.51259 & 0.512735 & 0.512641 & 0.51248 & 0.51255 & 0.51251 & 0.512552 & 0.51239 & 0.512630 & \\
\hline $2 \sigma$ & 0.000009 & 0.000007 & & 0.000015 & 0.000011 & & & & & & & \\
\hline$\varepsilon_{N d}$ & -6.7 & -6.3 & -0.9 & +1.9 & +0.1 & -3.1 & -1.7 & -2.5 & -1.7 & -4.8 & -0.2 & \\
\hline${ }^{176} \mathrm{Hf} /{ }^{177} \mathrm{Hf}$ & 0.282925 & 0.282942 & 0.283001 & 0.283064 & 0.283074 & 0.282804 & 0.282798 & 0.282786 & 0.282895 & 0.282693 & & \\
\hline $2 \sigma$ & 0.000007 & 0.000016 & 0.000011 & 0.000018 & 0.000007 & 0.000016 & 0.000015 & 0.000013 & 0.000008 & 0.000015 & & \\
\hline$\varepsilon_{H f}$ & +5.4 & +6.0 & +8.1 & +10.3 & +10.7 & +1.1 & +0.9 & +0.5 & +4.3 & -2.8 & & \\
\hline
\end{tabular}

Table 1 K-Ar ages, trace elements, $\mathrm{Nd}$ and $\mathrm{Hf}$ isotopic data of Luzon arc lavas. K-Ar ages and Nd isotopic data in italics are from Richard et al. 1986a, 1986b; Defant et al. 1990;

McDermott et al. 1993; Fourcade et al. 1994 and Maury et al. 1998. $\varepsilon_{\mathrm{Hf}}$ values were calculated with $\left({ }^{176} \mathrm{Hf} /{ }^{177} \mathrm{Hf}\right)_{\mathrm{CHUR}}=0.282772$ after Blichert-Toft and Albarède 1997 without an age correction. The reference values for BHVO-1 come from: ${ }^{1}$ Govindaraju (1994), ${ }^{2}$ Plank (pers comm) and ${ }^{3}$ Eggins et al. (1997) and are similar to other published values (Jenner et al., 1990, Raczek et al., 2001). Values measured for BIR-1 when samples were run are also given together with values (and 1 $\sigma$ ) for the Bora Bora in-house standard run over a long period of time. 


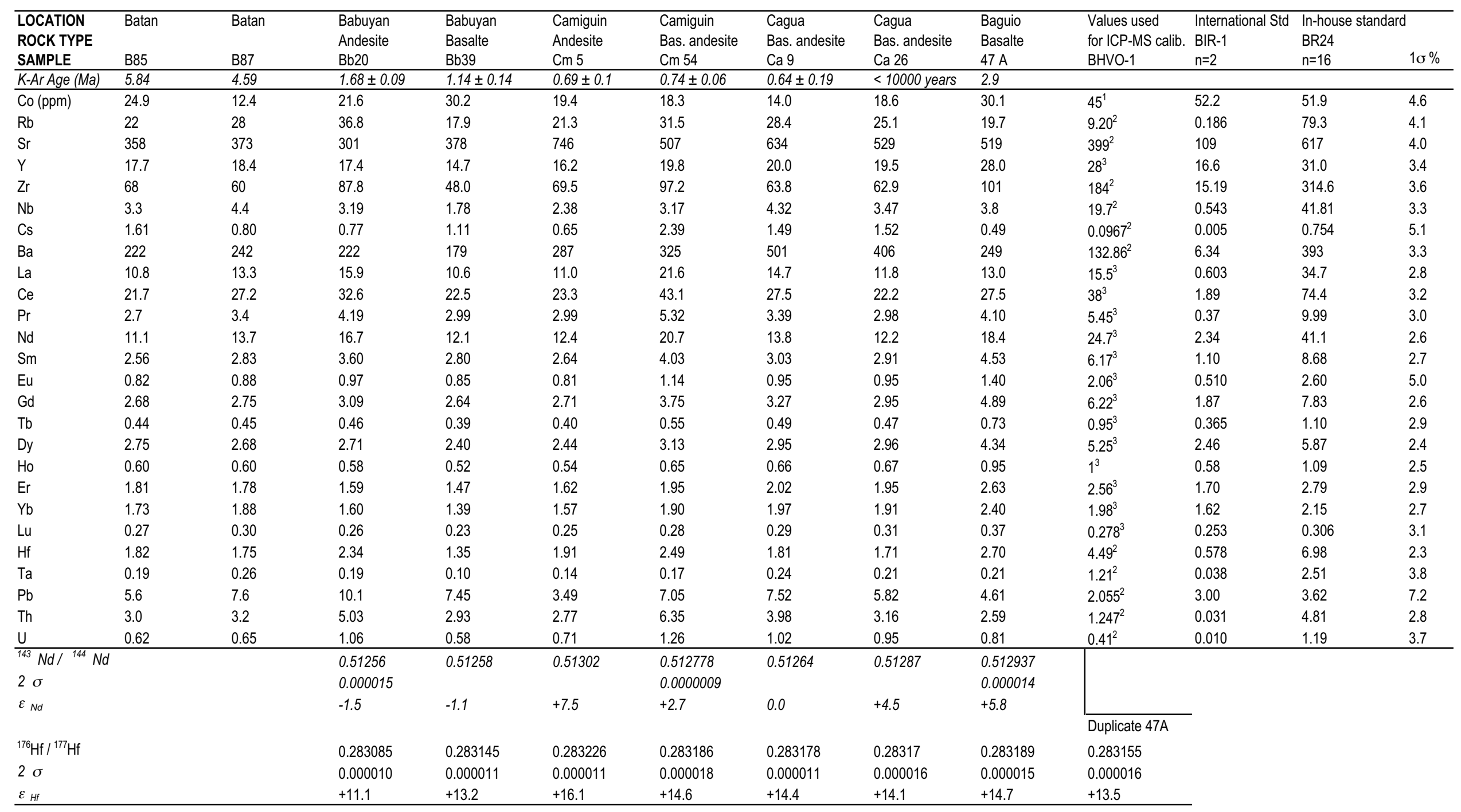




\begin{tabular}{|c|c|c|c|c|c|c|c|c|c|c|c|c|}
\hline $\begin{array}{l}\text { LOCATION } \\
\text { ROCK TYPE }\end{array}$ & $\begin{array}{l}\text { Lutao } \\
\text { Andesite }\end{array}$ & $\begin{array}{l}\text { Lutao } \\
\text { Andesite }\end{array}$ & $\begin{array}{l}\text { Lutao } \\
\text { Andesite }\end{array}$ & $\begin{array}{l}\text { Lanshu } \\
\text { Bas. andesite }\end{array}$ & $\begin{array}{l}\text { Lanshu } \\
\text { Bas. andesite }\end{array}$ & $\begin{array}{l}\text { Batan } \\
\text { Bas. andesite }\end{array}$ & $\begin{array}{l}\text { Batan } \\
\text { Bas. andesite }\end{array}$ & $\begin{array}{l}\text { Batan } \\
\text { Andesite }\end{array}$ & $\begin{array}{l}\text { Batan } \\
\text { Basalte }\end{array}$ & $\begin{array}{l}\text { Batan } \\
\text { Bas. andesite }\end{array}$ & Batan & Batan \\
\hline SAMPLE & TW 36 & TW 40 & TW 41 & TW 31 & TW 32 & B $3 \mathrm{~m}$ & B10 & B42 & B80 & B88 & B15 & B21 \\
\hline $\mathrm{SiO}_{2}(\mathrm{wt} \%)$ & 55.3 & 56.2 & 60.2 & 54.5 & 53.1 & 53.6 & 54.0 & 59.1 & 51.9 & 52.2 & 57 & 58.3 \\
\hline $\mathrm{TiO}_{2}$ & 0.61 & 0.54 & 0.52 & 0.82 & 0.73 & 0.95 & 0.97 & 0.95 & 0.81 & 1.12 & 0.77 & 0.75 \\
\hline $\mathrm{Al}_{2} \mathrm{O}_{3}$ & 18.1 & 18.45 & 18.9 & 18.9 & 16.85 & 19.85 & 18.36 & 16.98 & 15.57 & 18.64 & 18.53 & 17.84 \\
\hline $\mathrm{Fe}_{2} \mathrm{O}_{3}$ & 6.34 & 5.64 & 2.31 & 5.56 & 8.33 & & & 5.85 & 9.13 & 8.67 & 7.13 & 7.3 \\
\hline $\mathrm{MnO}$ & 0.13 & 0.11 & 0.07 & 0.10 & 0.15 & 0.17 & 0.16 & 0.09 & 0.16 & 0.16 & 0.15 & 0.18 \\
\hline $\mathrm{MgO}$ & 4.20 & 4.17 & 2.31 & 4.56 & 6.42 & 3.58 & 3.63 & 3.59 & 7.90 & 3.82 & 2.16 & 3.12 \\
\hline $\mathrm{CaO}$ & 7.41 & 7.03 & 6.95 & 9.54 & 9.32 & 8.21 & 8.29 & 6.64 & 11.13 & 8.84 & 6.15 & 7.32 \\
\hline $\mathrm{Na}_{2} \mathrm{O}$ & 3.56 & 3.66 & 3.71 & 3.40 & 3.06 & 3.47 & 3.55 & 3.86 & 2.57 & 3.33 & 3.58 & 3.65 \\
\hline $\mathrm{K}_{2} \mathrm{O}$ & 1.90 & 1.99 & 1.48 & 1.11 & 1.02 & 2.27 & 2.11 & 2.69 & 1.11 & 2.51 & 0.92 & 0.75 \\
\hline $\mathrm{P}_{2} \mathrm{O}_{5}$ & 0.34 & 0.25 & 0.11 & 0.05 & 0.04 & 0.45 & 0.45 & 0.35 & 0.15 & 0.40 & 0.15 & 0.2 \\
\hline LOI & 1.18 & 1.43 & 0.76 & 0.92 & 0.30 & 0.22 & 0.34 & 0.03 & 0.19 & -0.04 & 1.99 & 0.48 \\
\hline $\mathrm{H}_{2} \mathrm{O}$ & 0.28 & 0.27 & 0.63 & 0.62 & 0.23 & 0.50 & 1.45 & 0.06 & 0.37 & 0.16 & 1.25 & 0.27 \\
\hline Total & 99.35 & 99.74 & 100.2 & 99.99 & 99.11 & & & 100.19 & 100.99 & 99.81 & 99.78 & 100.16 \\
\hline${ }^{87} \mathrm{Sr} /{ }^{86} \mathrm{Sr}$ & 0.706102 & 0.706013 & 0.70483 & 0.704313 & 0.705452 & 0.70476 & 0.70445 & 0.70393 & 0.70396 & 0.70545 & 0.705030 & \\
\hline $2 \sigma$ & 0.000006 & 0.000009 & & 0.000008 & 0.000006 & & & & & & & \\
\hline${ }^{206} \mathrm{~Pb} /{ }^{204} \mathrm{~Pb}$ & 18.424 & 18.429 & 18.412 & 18.298 & 18.394 & 18.455 & 18.298 & 18.36 & 18.351 & 18.378 & & \\
\hline${ }^{207} \mathrm{~Pb} /{ }^{204} \mathrm{~Pb}$ & 15.639 & 15.637 & 15.611 & 15.573 & 15.622 & 15.64 & 15.538 & 15.558 & 15.571 & 15.594 & & \\
\hline${ }^{208} \mathrm{~Pb} /{ }^{204} \mathrm{~Pb}$ & 38.845 & 38.83 & 38.698 & 38.561 & 38.781 & 38.834 & 38.492 & 38.516 & 38.515 & 38.661 & & \\
\hline$\delta^{18} 0$ & +6.91 & +6.48 & +7.92 & +6.61 & +6.39 & +6.51 & & +6.11 & +5.97 & +6.15 & & \\
\hline
\end{tabular}

Appendix: Major elements, $\mathrm{Sr}, \mathrm{Pb}$ and $\mathrm{O}$ isotopic data of the Luzon arc lavas analysed for trace elements and $\mathrm{Hf}$ isotopic compositions. Data from Richard et al. 1986a, 1986b; Vidal et al. 1989; Defant et al. 1990; McDermott et al. 1993; Fourcade et al. 1994 and Maury et al. 1998. 


\begin{tabular}{|c|c|c|c|c|c|c|c|c|c|c|c|}
\hline $\begin{array}{l}\text { LOCATION } \\
\text { ROCK TYPE } \\
\text { SAMPLE }\end{array}$ & Batan & Batan & $\begin{array}{l}\text { Babuyan } \\
\text { Andesite } \\
\text { Bd20 }\end{array}$ & $\begin{array}{l}\text { Babuyan } \\
\text { Basalte } \\
\text { Bd39 }\end{array}$ & $\begin{array}{l}\text { Calayan } \\
\text { Andesite } \\
\text { Cl } 1\end{array}$ & $\begin{array}{l}\text { Calayan } \\
\text { Bas. andesite } \\
\mathrm{Cl} 16\end{array}$ & $\begin{array}{l}\text { Camiguin } \\
\text { Andesite } \\
\mathrm{Cm} 5\end{array}$ & $\begin{array}{l}\text { Camiguin } \\
\text { Bas. andesite } \\
\text { Cm 54 }\end{array}$ & $\begin{array}{l}\text { Cagua } \\
\text { Bas. andesite } \\
\text { Ca } 9\end{array}$ & $\begin{array}{l}\text { Cagua } \\
\text { Bas. andesite } \\
\text { Ca } 26\end{array}$ & $\begin{array}{l}\text { Baguio } \\
\text { Basalte } \\
47 \mathrm{~A}\end{array}$ \\
\hline$\overline{\mathrm{SiO}_{2}(\mathrm{wt} \%)}$ & 51 & 56.8 & 55.7 & 51.3 & 57.7 & 55.5 & 58.25 & 53.8 & 55.2 & 53.3 & 48.5 \\
\hline $\mathrm{TiO}_{2}$ & 0.95 & 0.81 & 0.83 & 0.81 & 0.81 & 0.91 & 0.74 & 1.05 & 0.92 & 1.05 & 1.29 \\
\hline $\mathrm{Al}_{2} \mathrm{O}_{3}$ & 20.36 & 18.42 & 17.67 & 18.38 & & 16.9 & & 18.48 & & & 19.25 \\
\hline $\mathrm{Fe}_{2} \mathrm{O}_{3}$ & 7.97 & 6.4 & 7.88 & 9.75 & & 8.26 & & 6.78 & & & 11.18 \\
\hline $\mathrm{MnO}$ & 0.15 & 0.15 & 0.14 & 0.17 & & 0.16 & & 0.14 & & & 0.16 \\
\hline $\mathrm{MgO}$ & 5.53 & 2.92 & 4.01 & 5.21 & & 5.17 & 4.44 & 4.26 & 2.73 & 3.59 & 4.19 \\
\hline $\mathrm{CaO}$ & 10.29 & 7.31 & 8.46 & 10.66 & & 9.60 & & 9.10 & & & 10.5 \\
\hline $\mathrm{Na}_{2} \mathrm{O}$ & 3.06 & 3.49 & 3.39 & 2.72 & & 3.06 & & 3.37 & & & 3.06 \\
\hline $\mathrm{K}_{2} \mathrm{O}$ & 0.58 & 0.99 & 1.21 & 0.74 & 0.49 & 0.37 & 1.19 & 1.45 & 1.32 & 1.12 & 1.07 \\
\hline $\mathrm{P}_{2} \mathrm{O}_{5}$ & 0.15 & 0.2 & 0.10 & 0.10 & & 0.10 & & 0.20 & & & 0.20 \\
\hline LOI & 0.79 & 1.81 & 0.25 & 0.0 & 0.45 & 0.17 & 0.23 & 1.26 & & & 0.62 \\
\hline $\mathrm{H}_{2} \mathrm{O}$ & 0.41 & 0.15 & 0.24 & 0.15 & & 0.13 & & 0.22 & & & 0.28 \\
\hline Total & 101.24 & 99.45 & 99.88 & 99.16 & & 100.33 & & 100.11 & & & 100.3 \\
\hline${ }^{87} \mathrm{Sr} /{ }^{86} \mathrm{Sr}$ & & & 0.704565 & 0.70448 & 0.7037 & 0.703707 & 0.70327 & 0.704078 & 0.70386 & 0.70395 & 0.703774 \\
\hline $2 \sigma$ & & & 0.000007 & & & 0.000019 & & 0.000009 & & & 0.000008 \\
\hline${ }^{206} \mathrm{~Pb} /{ }^{204} \mathrm{~Pb}$ & & & 18.531 & 18.515 & & 18.274 & 18.37 & 18.5 & 18.502 & 18.569 & 18.348 \\
\hline${ }^{207} \mathrm{~Pb} /{ }^{204} \mathrm{~Pb}$ & & & 15.614 & 15.621 & & 15.554 & 15.543 & 15.609 & 15.574 & 15.615 & 15.532 \\
\hline${ }^{208} \mathrm{~Pb} /{ }^{204} \mathrm{~Pb}$ & & & 38.837 & 38.782 & & 38.348 & 38.425 & 38.731 & 38.645 & 38.804 & 38.343 \\
\hline$\delta^{18} 0$ & & & +7.02 & +6.13 & +6.86 & +6.98 & +6.7 & +7.3 & & & +6.69 \\
\hline
\end{tabular}




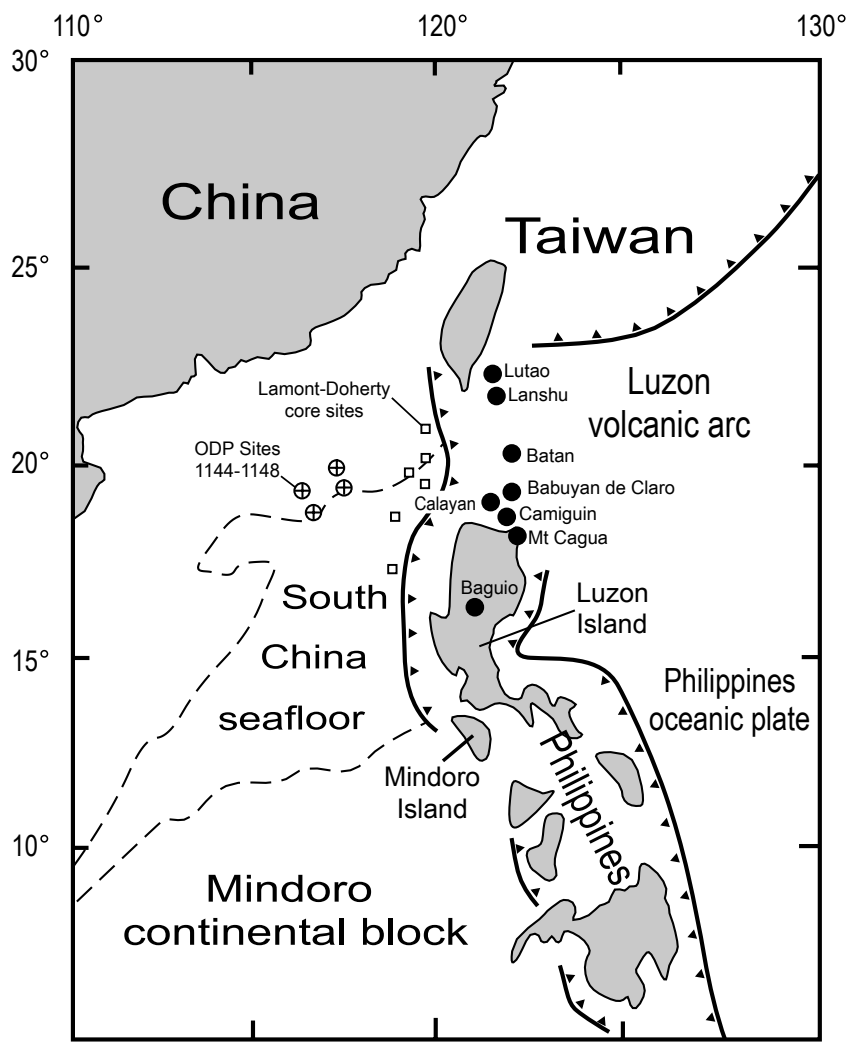




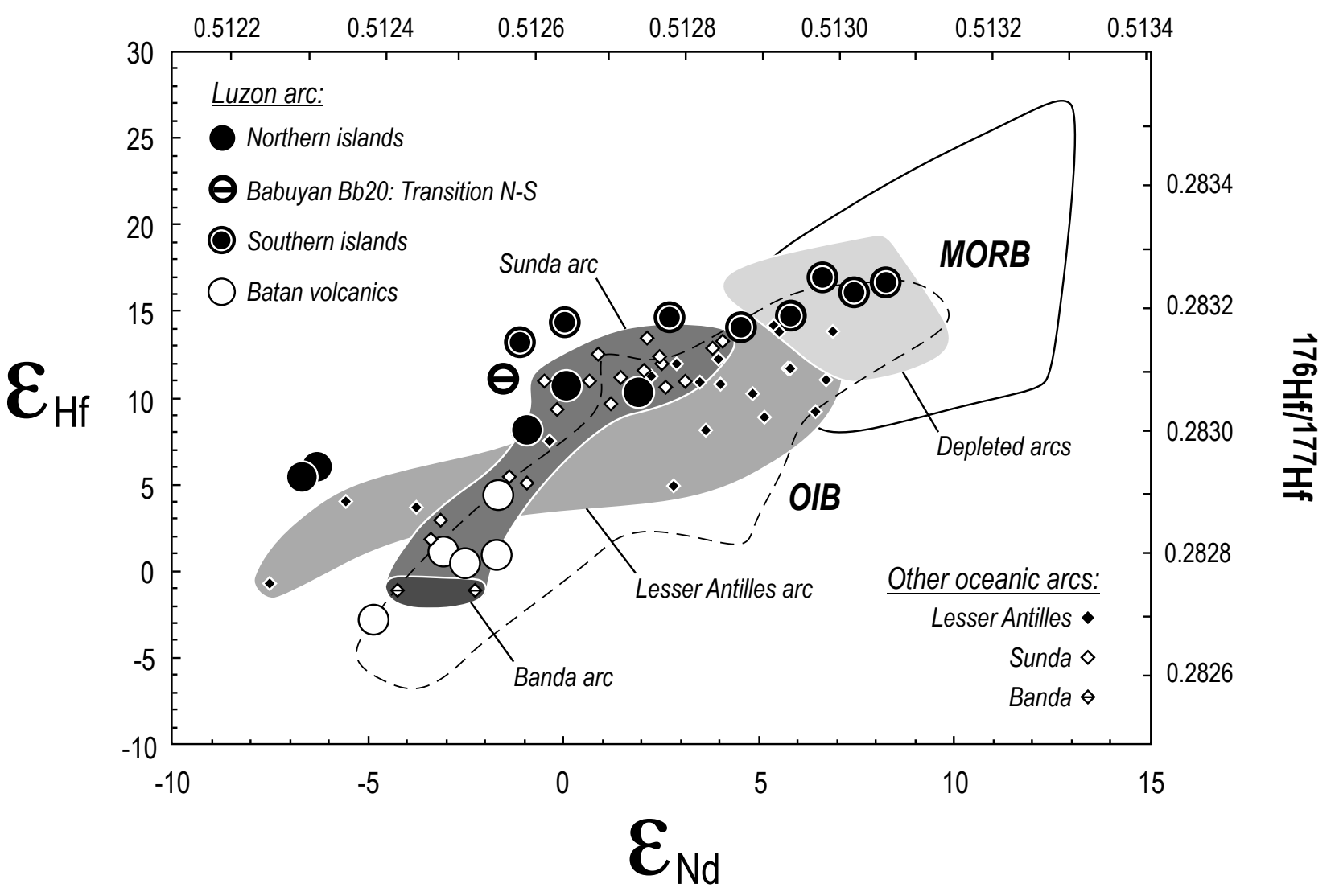


Figure 3

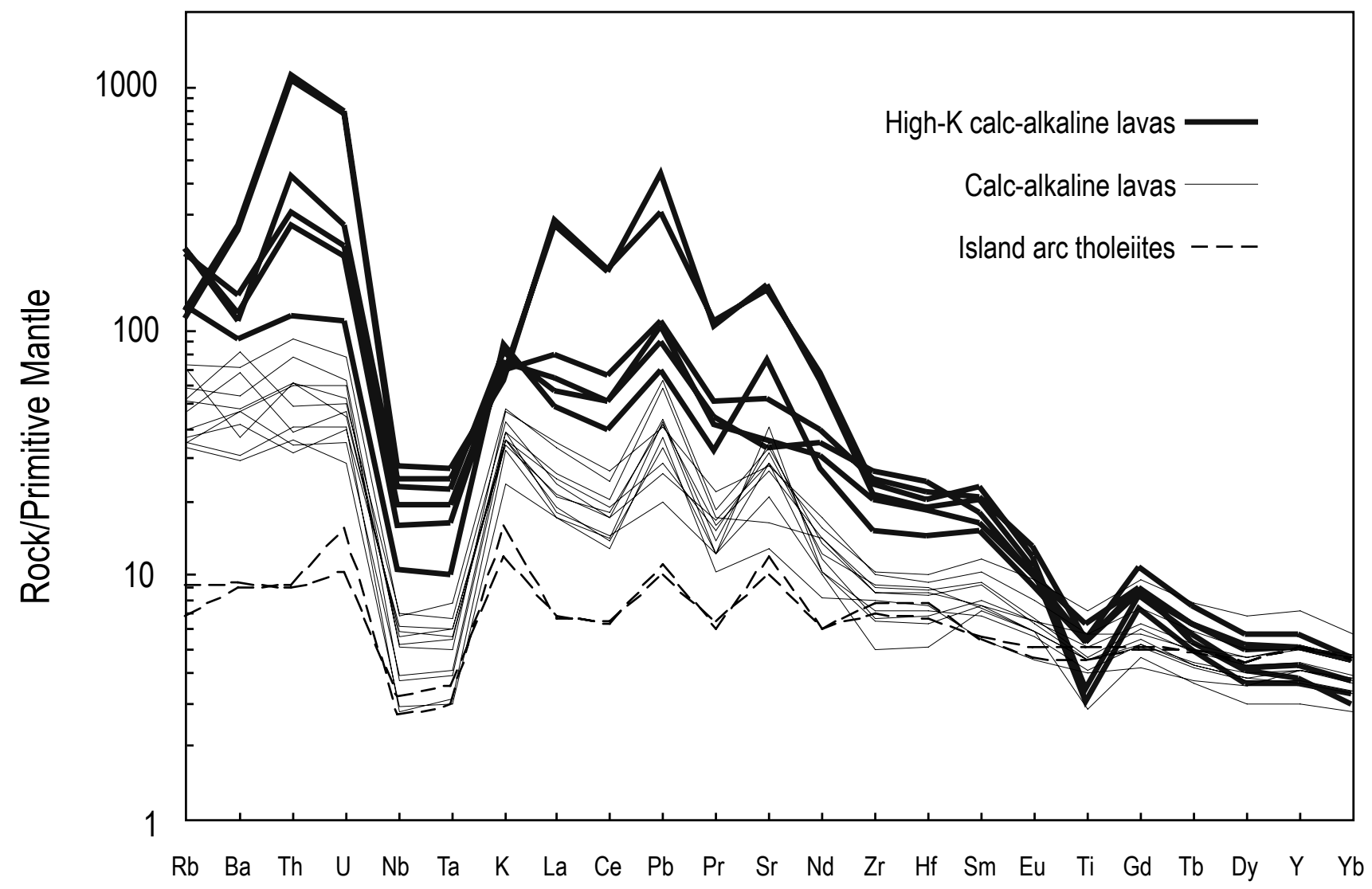




\section{${ }^{176} \mathrm{Hf} /{ }^{177} \mathrm{Hf}$}

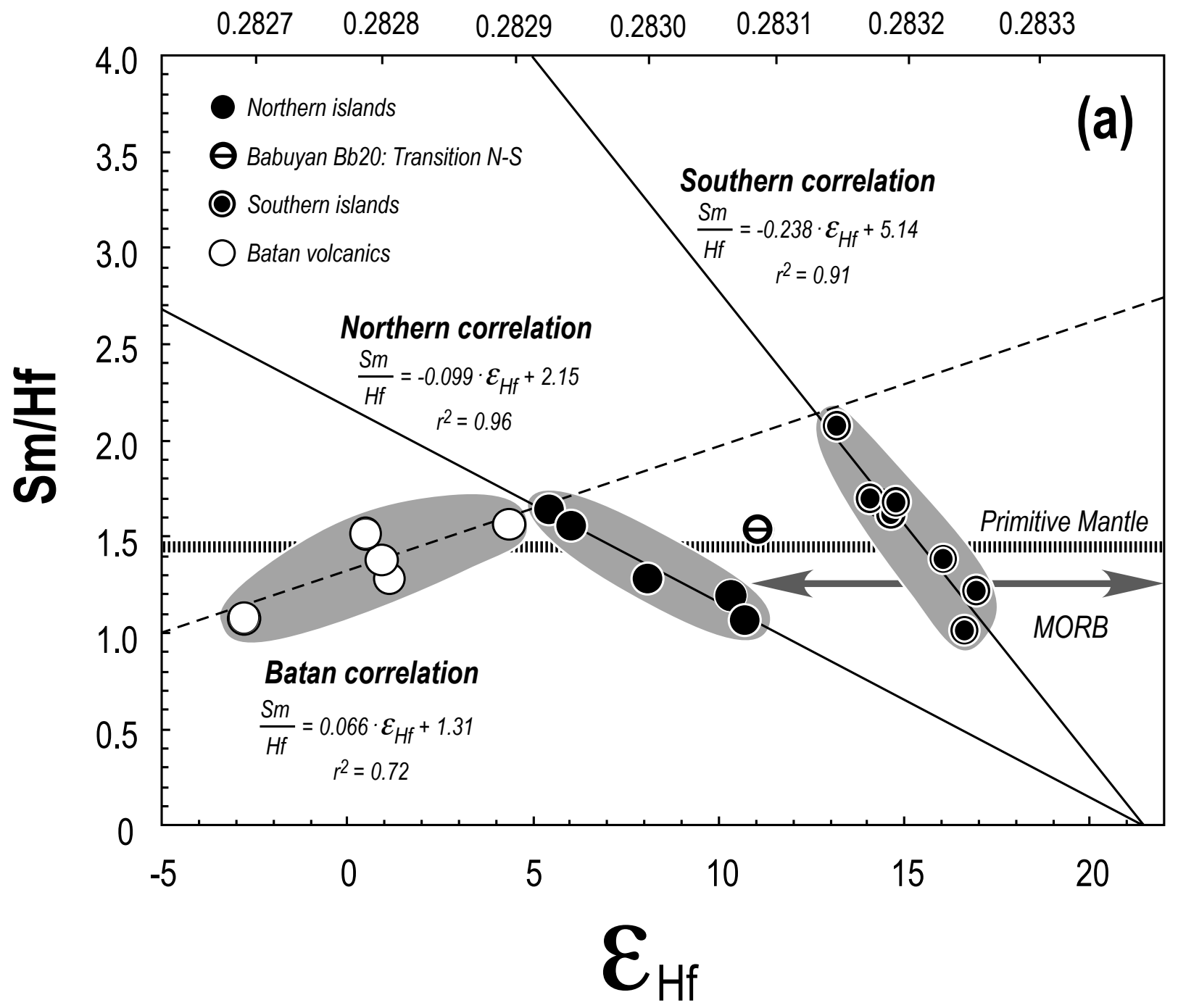




\section{${ }^{176} \mathrm{Hf} /{ }^{177} \mathrm{Hf}$}

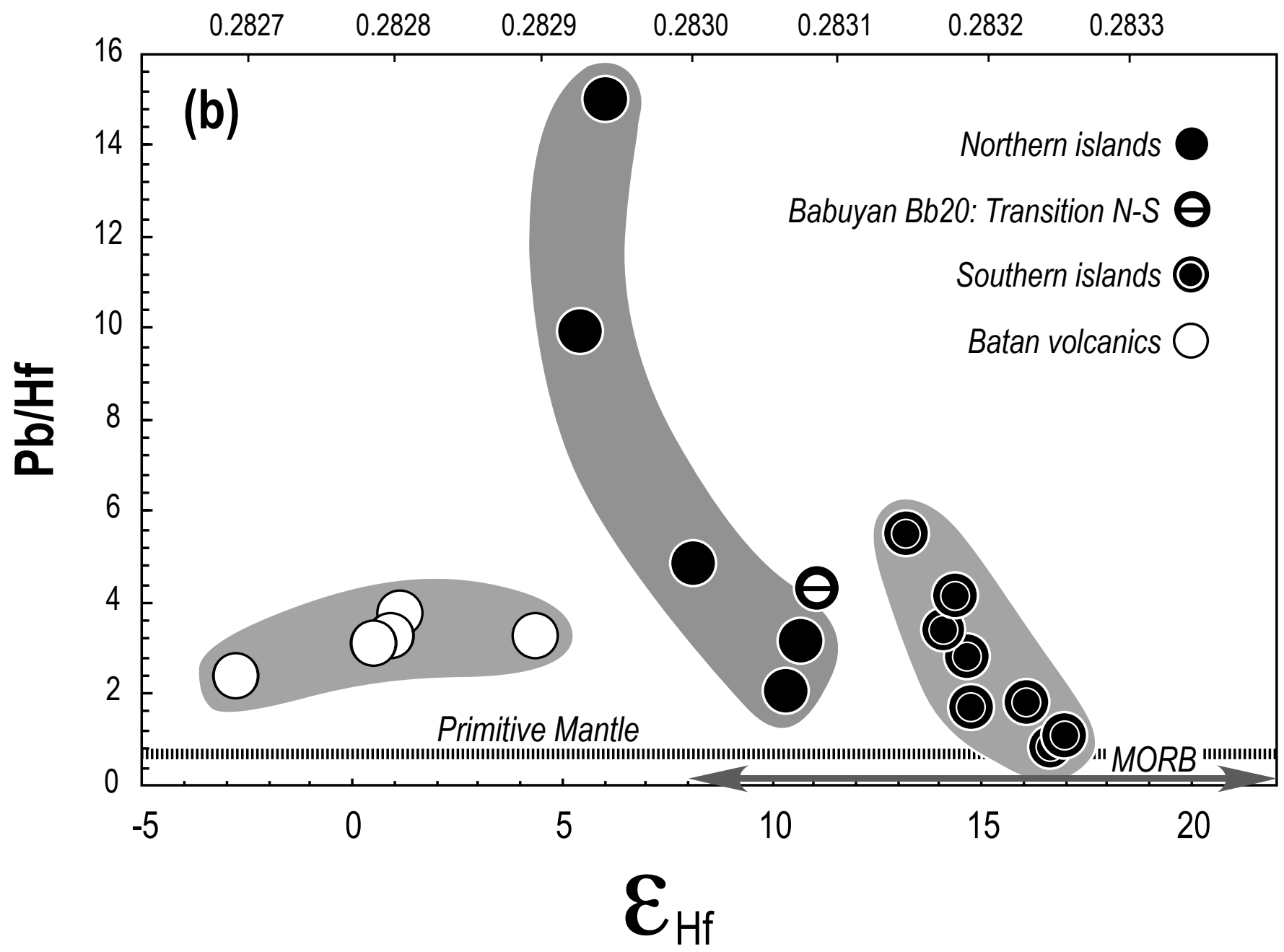


Figure 4c

${ }^{176} \mathrm{Hf} /{ }^{177} \mathrm{Hf}$

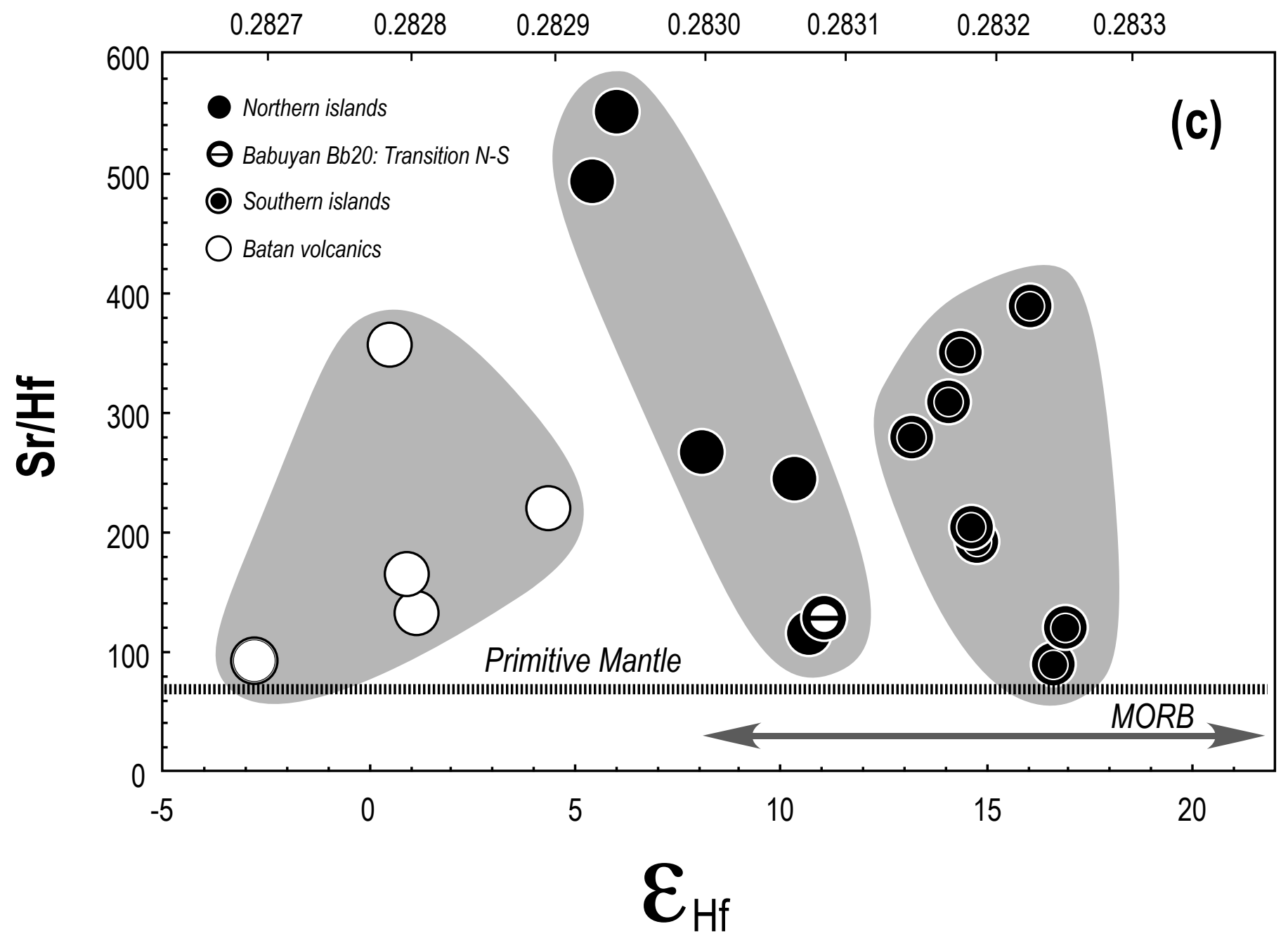




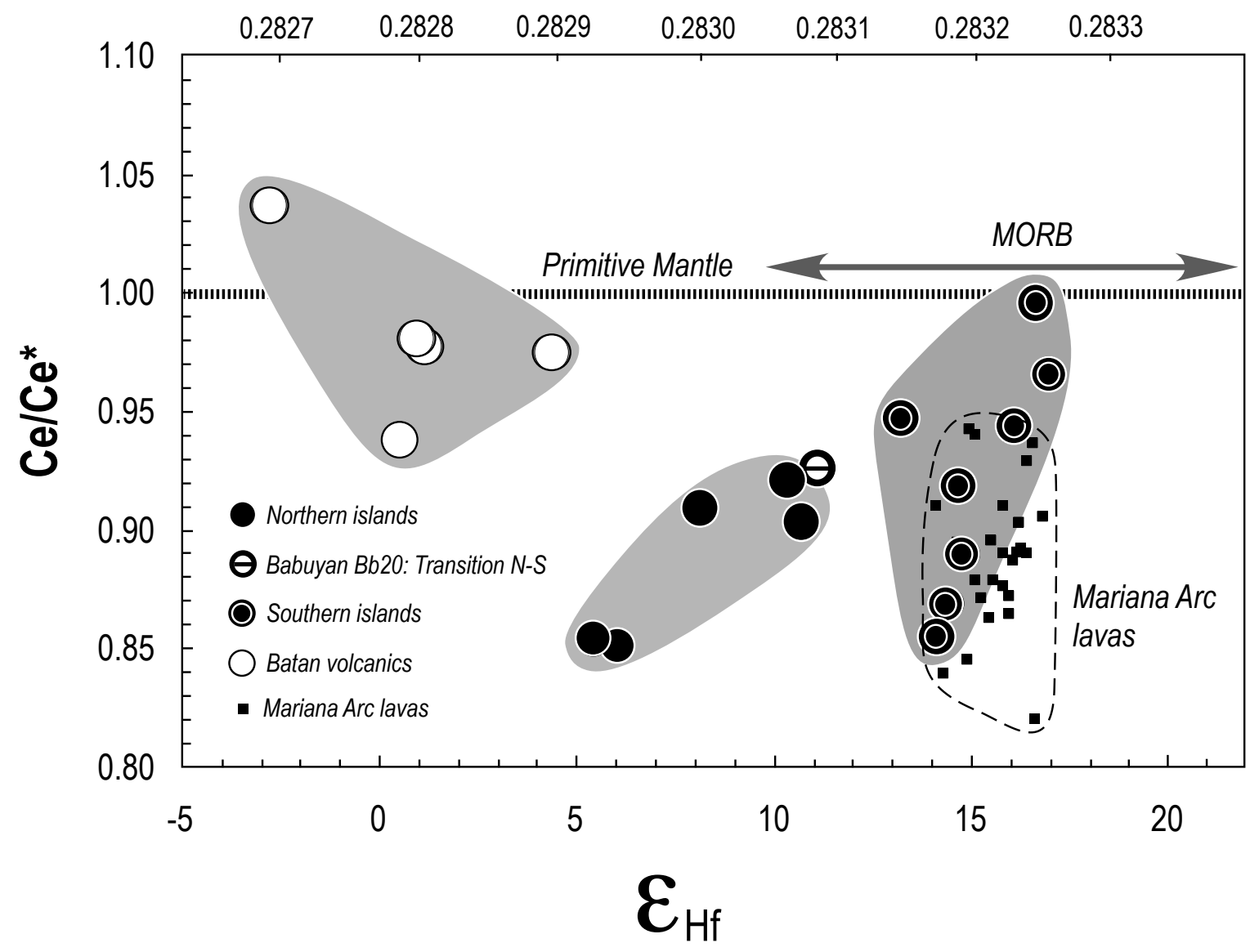


${ }^{143} \mathrm{Nd} /{ }^{144} \mathrm{Nd}$

Figure 6

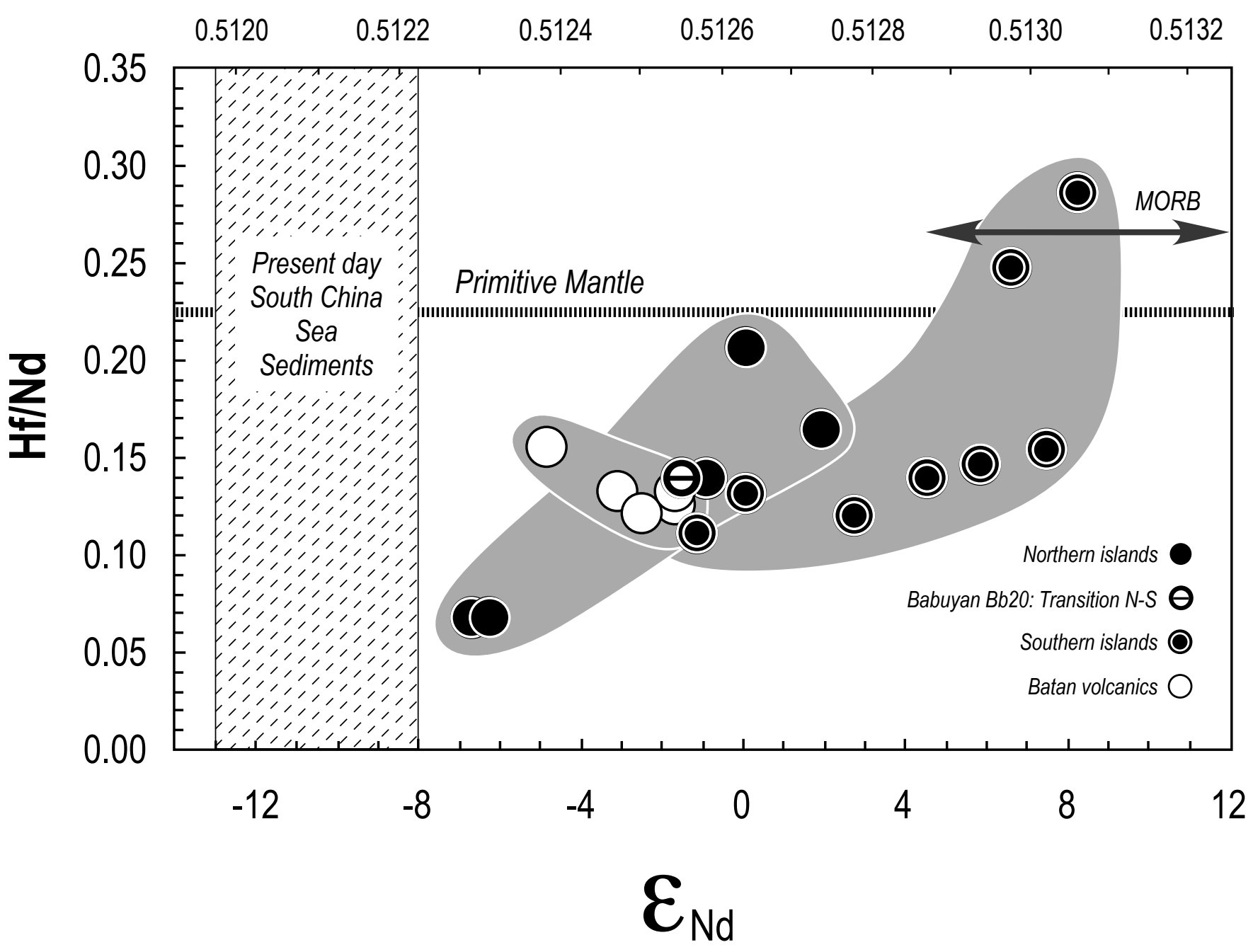




\section{${ }^{143} \mathrm{Nd} /{ }^{144} \mathrm{Nd}$}

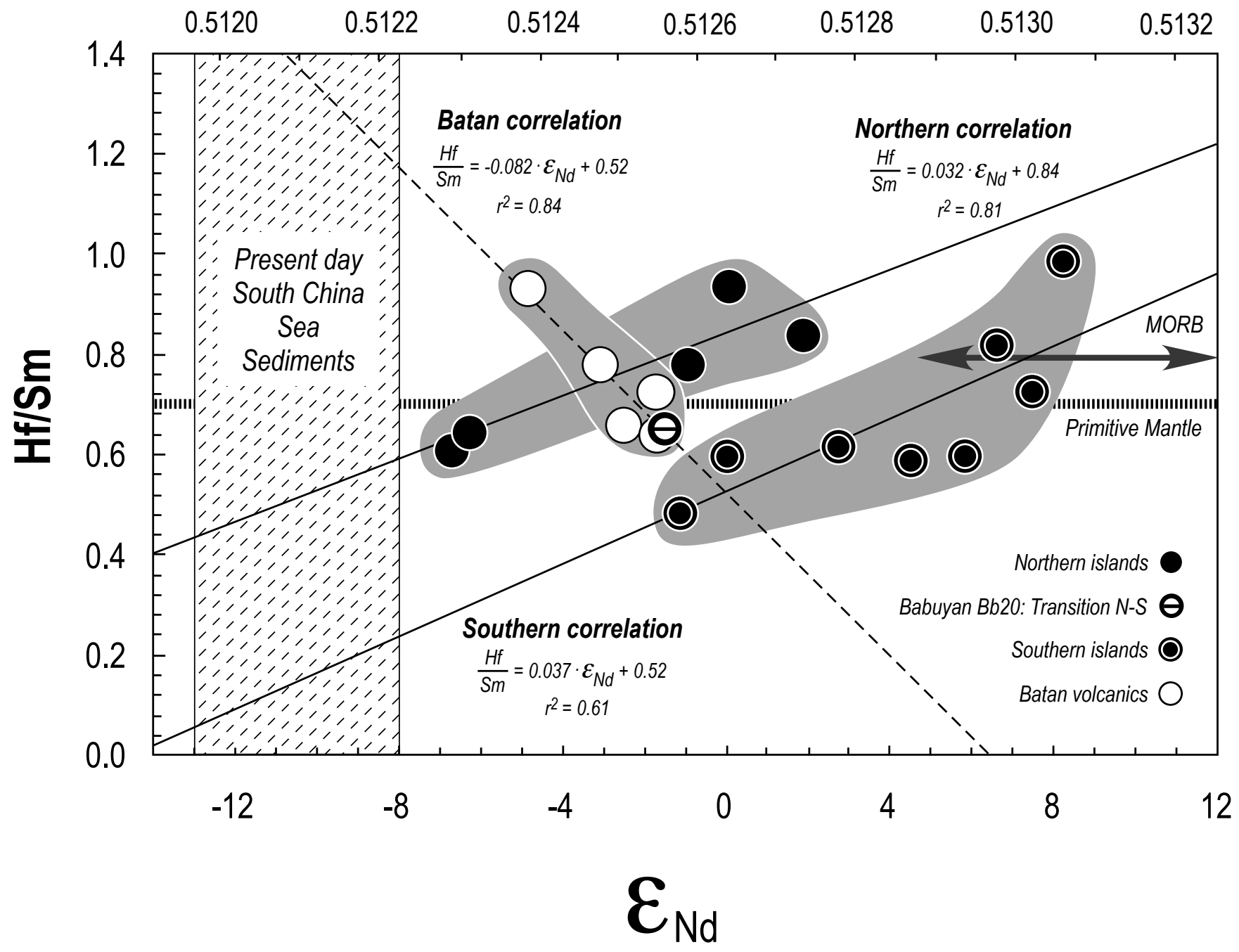




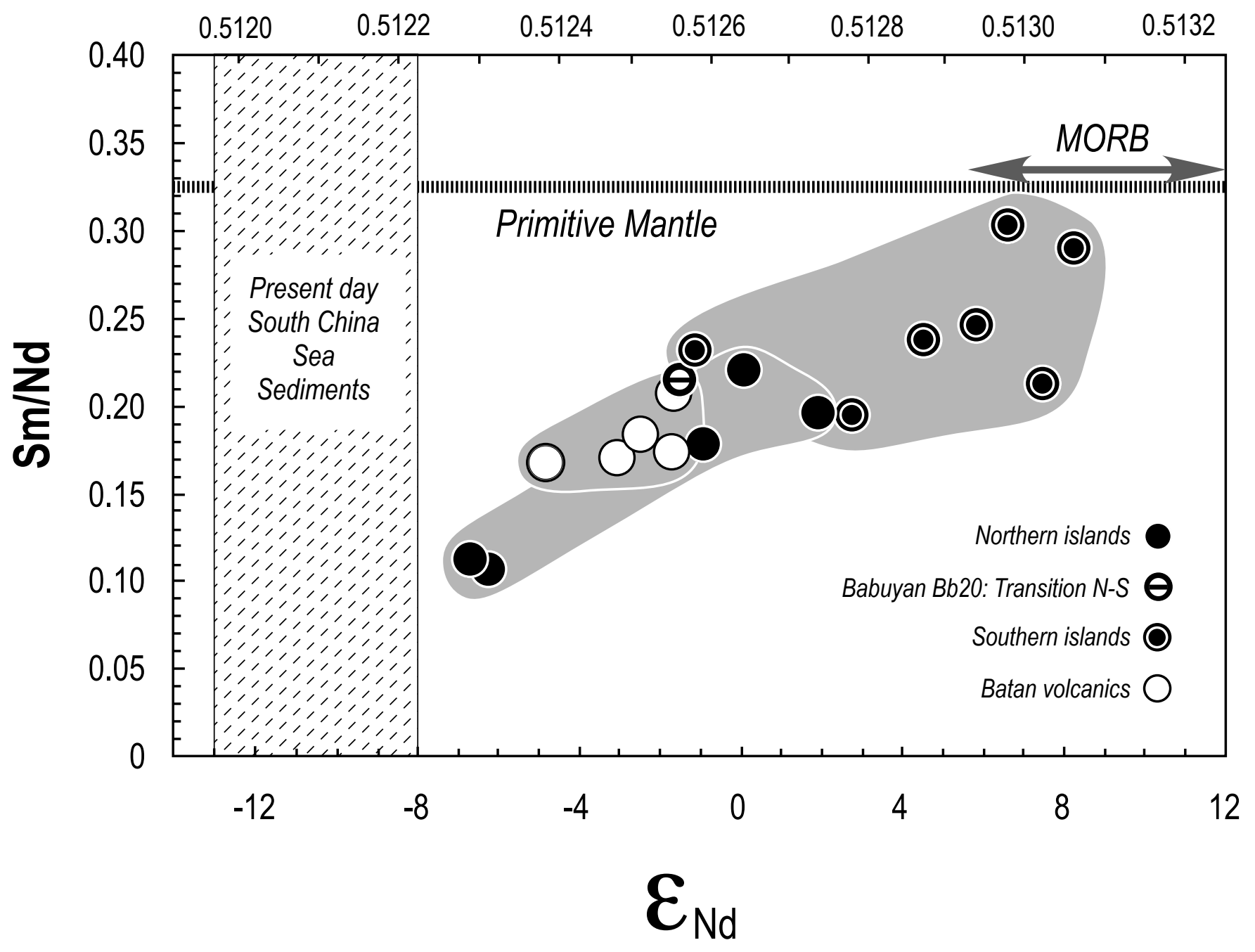




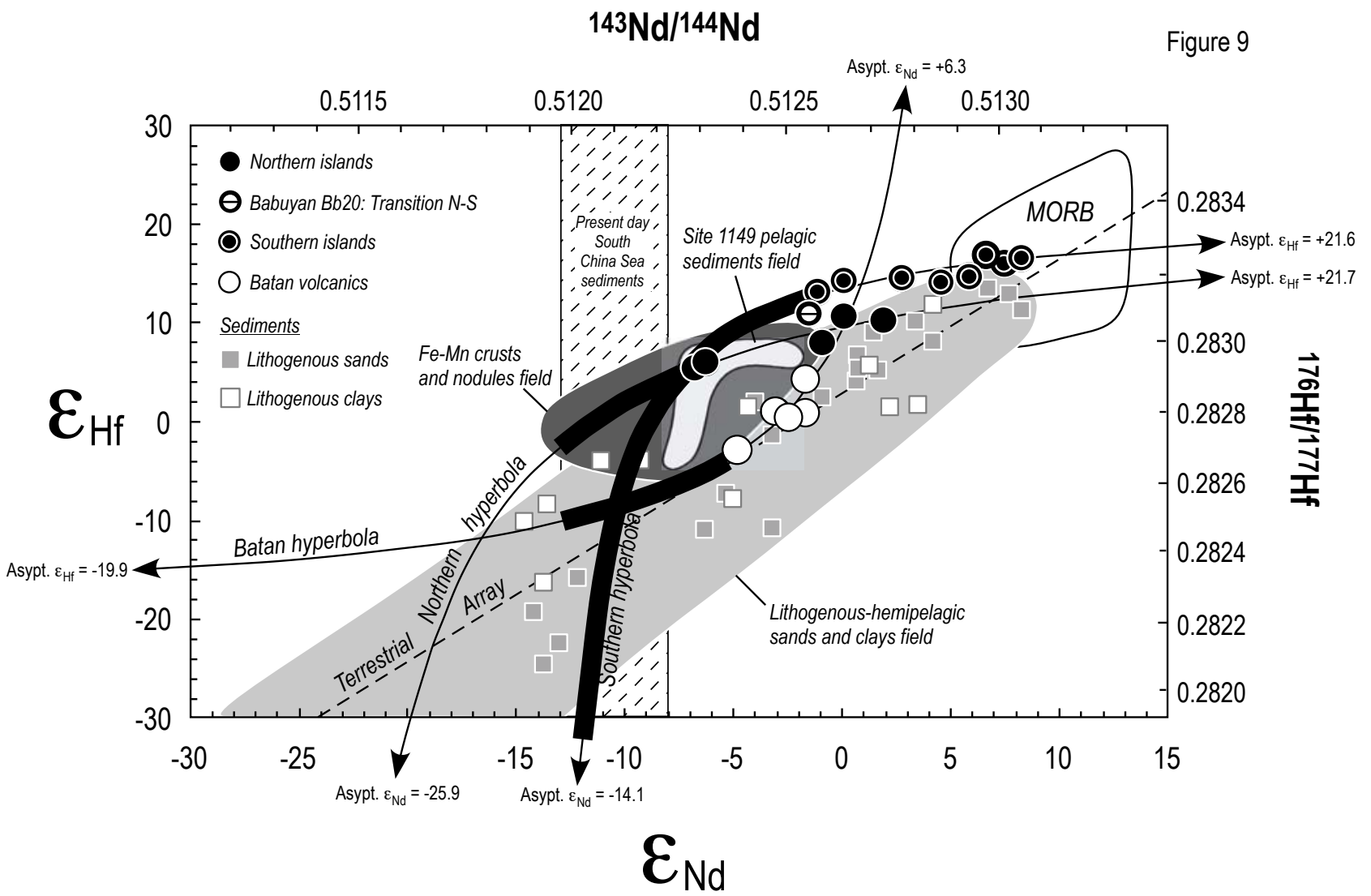


${ }^{176} \mathrm{Hf} /{ }^{177} \mathrm{Hf}$

Figure 10

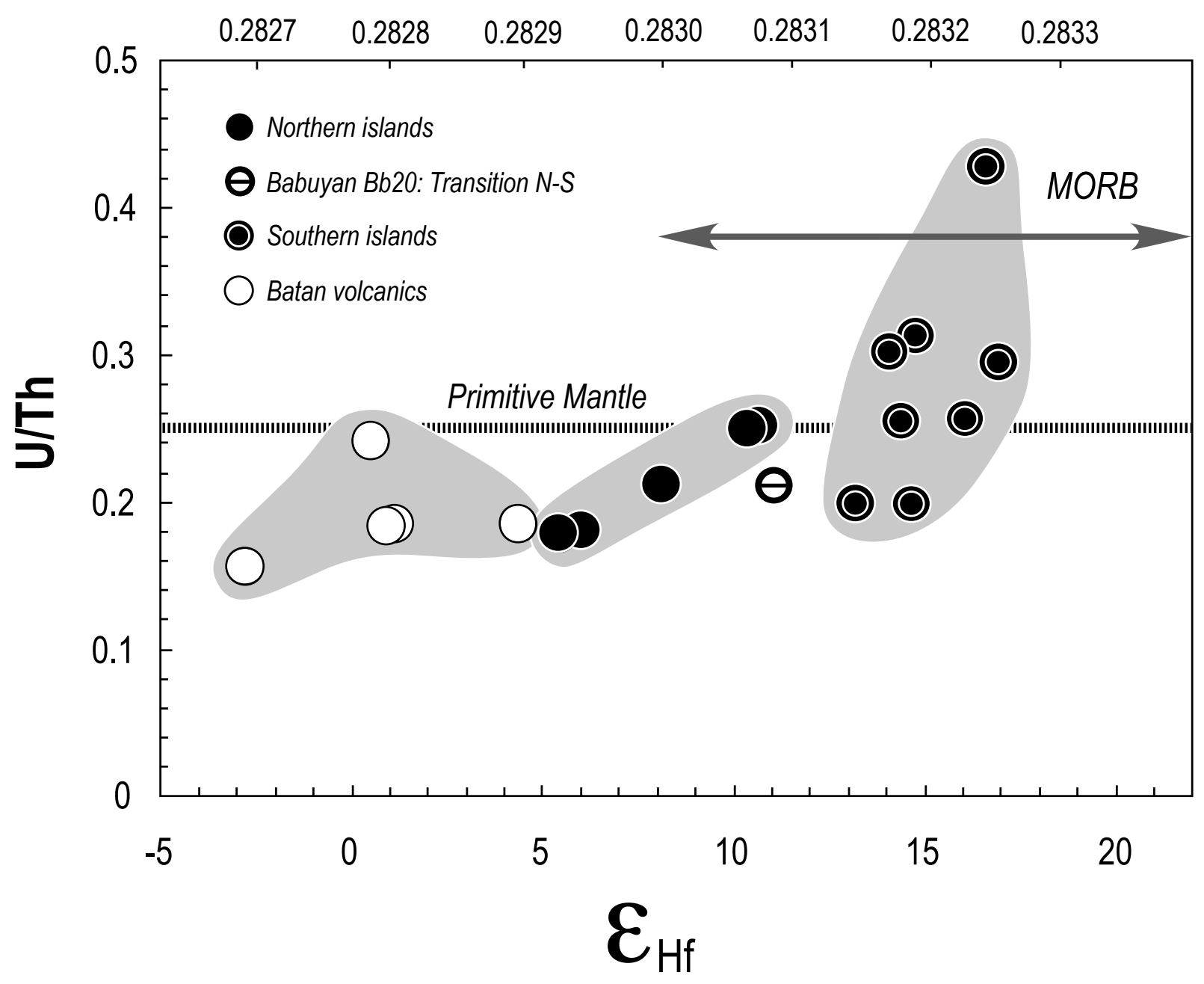




\section{${ }^{176} \mathrm{Hf} /{ }^{177} \mathrm{Hf}$}

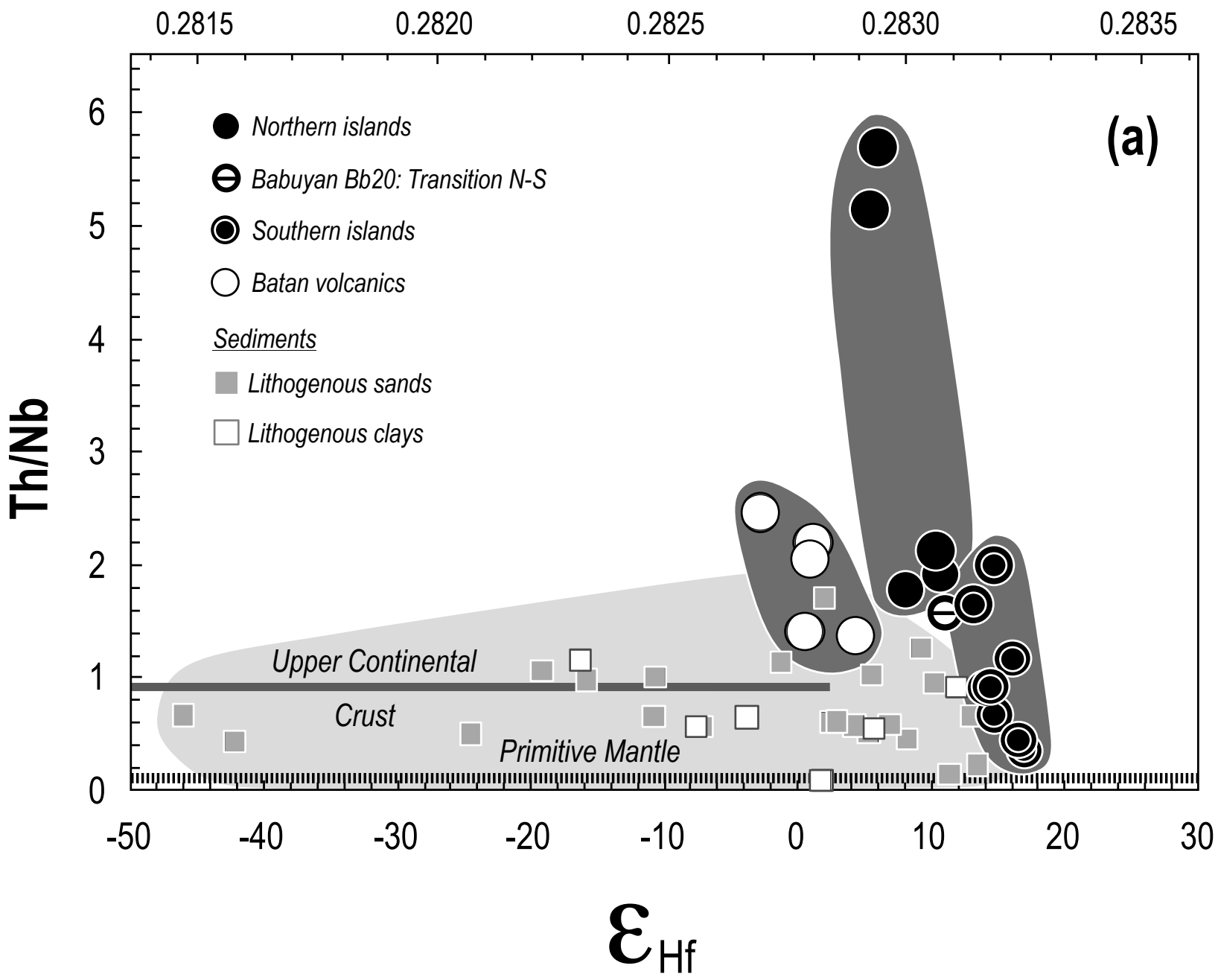




\section{${ }^{176} \mathrm{Hf} /{ }^{177} \mathrm{Hf}$}

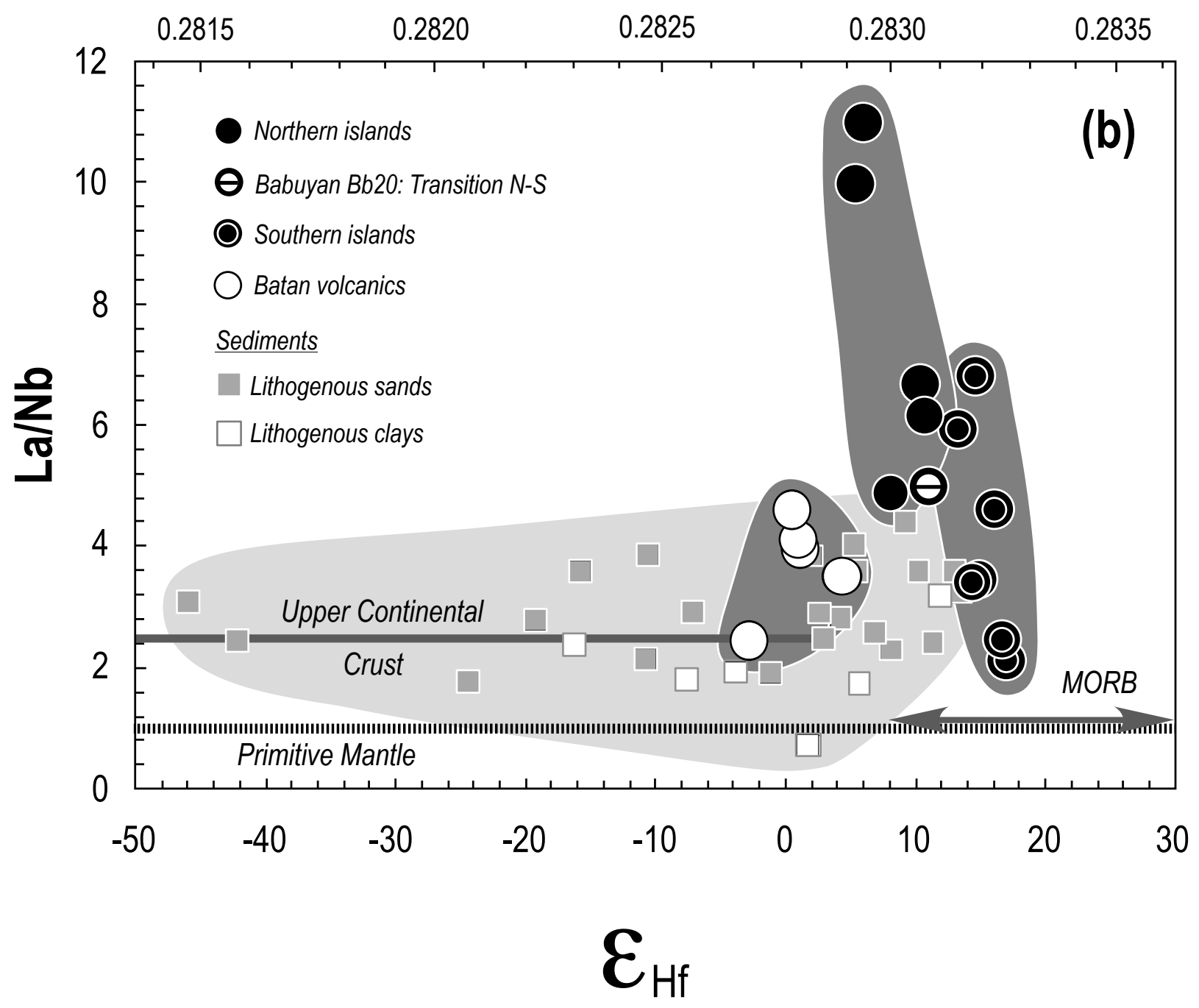


Electronic supplementary data set

Comparison of new trace element data acquired by ICP-MS and published values.

\begin{tabular}{|c|c|c|c|c|c|c|c|c|c|c|c|c|c|c|c|c|c|c|c|c|c|}
\hline \multirow{3}{*}{$\begin{array}{c}\text { Location } \\
\text { Sample name } \\
\text { Conc. in ppm }\end{array}$} & \multirow[b]{3}{*}{ published } & \multicolumn{4}{|c|}{ Lutao } & \multicolumn{7}{|c|}{ Lanshu } & \multirow[b]{3}{*}{ published } & \multirow{3}{*}{$\begin{array}{l}\text { B 3M } \\
\text { new }\end{array}$} & \multirow[b]{3}{*}{ diff in $\%$} & \multirow[b]{3}{*}{ published } & \multirow{3}{*}{$\begin{array}{l}\text { B10 } \\
\text { new }\end{array}$} & \multirow[b]{3}{*}{ diff in $\%$} & \multicolumn{3}{|c|}{ Batan } \\
\hline & & TW36 & & & TW40 & & & TW31 & & & TW32 & & & & & & & & & B42 & \\
\hline & & new & diff in $\%$ & published & new & diff in $\%$ & published & new & diff in $\%$ & published & new & diff in $\%$ & & & & & & & published & new & diff in $\%$ \\
\hline $\mathrm{Cr}$ & 79 & & & 88 & & & 49 & & & 198 & & & & & & & & & & & \\
\hline $\mathrm{Ni}$ & 38 & & & 42 & & & 16 & & & 83 & & & & & & & & & & & \\
\hline Co & 17 & 16.9 & -1 & 16 & 15.5 & -3 & 18 & 13.6 & -32 & 27 & 19.1 & -41 & & 18.6 & & & 19.2 & & & 18.2 & \\
\hline $\mathrm{Rb}$ & 61 & 63.2 & 3 & 63 & 59.2 & -6 & 18 & 18.8 & 4 & 13 & 18.8 & 31 & 107 & 114 & 6 & 105 & 107 & 2 & 61 & 65.9 & 7 \\
\hline $\mathrm{Sr}$ & 2984 & 2622 & -14 & 2896 & 2743 & -6 & 568 & 582 & 2 & 334 & 232 & -44 & 648 & 641 & -1 & 894 & 953 & 6 & 1225 & 1366 & 10 \\
\hline Y & & 16.4 & & & 14.0 & & & 16.0 & & & 16.2 & & & 19.6 & & 20 & 22.2 & 10 & 13.8 & 14.5 & 5 \\
\hline $\mathrm{Zr}$ & 211 & 224 & 6 & 274 & 203 & -35 & 68 & 88.4 & 23 & 74 & 77.3 & 4 & 196 & 195 & -1 & 215 & 237 & 9 & 120 & 143 & 16 \\
\hline $\mathrm{Nb}$ & & 17.0 & & & 14.9 & & & 2.27 & & & 1.72 & & & 9.74 & & 10.6 & 11.8 & 10 & 5.5 & 6.40 & 14 \\
\hline Cs & & 7.51 & & & 7.45 & & & 0.74 & & & 0.50 & & & 8.69 & & & 9.05 & & & 2.75 & \\
\hline $\mathrm{Ba}$ & 1534 & 1594 & 4 & 1558 & 1524 & -2 & 278 & 282 & 1 & 138 & 186 & 26 & 626 & 701 & 11 & 800 & 826 & 3 & 520 & 549 & 5 \\
\hline La & 158 & 169 & 7 & 165 & 164 & -1 & 13.82 & 15.1 & 8 & 7.83 & 10.6 & 26 & 38.5 & 38.6 & 0 & 48 & 48.6 & 1 & 28.5 & 29.5 & 3 \\
\hline $\mathrm{Ce}$ & 271 & 282 & 4 & 285 & 271 & -5 & 32.88 & 30.2 & -9 & 19.33 & 20.5 & 6 & 73.7 & 81.6 & 10 & 98 & 103 & 5 & 59 & 61.4 & 4 \\
\hline $\mathrm{Pr}$ & & 25.8 & & & 24.5 & & & 3.72 & & & 2.50 & & & 9.69 & & & 12.2 & & & 7.74 & \\
\hline $\mathrm{Nd}$ & 13.44 & 77.6 & 83 & & 72.4 & & 14.92 & 14.5 & -3 & 9.49 & 9.65 & 2 & 38.4 & 36.2 & -6 & 46 & 45.8 & 0 & 31 & 31.6 & 2 \\
\hline $\mathrm{Sm}$ & 9.69 & 8.73 & -11 & 8.1 & 7.75 & -5 & 3.2 & 2.84 & -13 & 2.46 & 2.13 & -15 & 6.46 & 6.17 & -5 & & 7.96 & & & 5.81 & \\
\hline Eu & 1.96 & 1.72 & -14 & 1.73 & 1.55 & -12 & 1.01 & 0.85 & -19 & 0.81 & 0.66 & -23 & & 1.44 & & 1.8 & 1.87 & 4 & 1.28 & 1.30 & 2 \\
\hline $\mathrm{Gd}$ & 2.19 & 4.19 & 48 & 5.46 & 3.68 & -48 & 6.7 & 2.69 & -149 & 2.62 & 2.14 & -22 & & 4.24 & & 5.2 & 5.38 & 3 & 3.8 & 4.47 & 15 \\
\hline $\mathrm{Tb}$ & 0.48 & 0.52 & 8 & 0.39 & 0.46 & 15 & 0.39 & 0.41 & 5 & 0.37 & 0.35 & -6 & & 0.58 & & & 0.69 & & & 0.49 & \\
\hline Dy & 2.73 & 2.61 & -5 & & 2.25 & & 2.63 & 2.54 & -4 & 2.53 & 2.25 & -12 & & 3.13 & & 3.5 & 3.62 & 3 & 2.4 & 2.54 & 6 \\
\hline Ho & & 0.52 & & & 0.43 & & & 0.55 & & & 0.51 & & & 0.65 & & & 0.72 & & & 0.50 & \\
\hline $\mathrm{Er}$ & 1.54 & 1.55 & 1 & & 1.33 & & 1.49 & 1.60 & 7 & 1.56 & 1.60 & 3 & & 1.92 & & 2 & 2.08 & 4 & 1.2 & 1.23 & 2 \\
\hline $\mathrm{Yb}$ & 1.56 & 1.51 & -3 & 2.5 & 1.34 & -87 & 1.56 & 1.48 & -5 & 1.71 & 1.54 & -11 & 1.82 & 1.84 & 1 & 1.94 & 1.89 & -3 & 1.1 & 1.21 & 9 \\
\hline Lu & 0.27 & 0.24 & -13 & & 0.21 & & 0.21 & 0.25 & 16 & 0.22 & 0.26 & 15 & & 0.30 & & & 0.30 & & & 0.17 & \\
\hline $\mathrm{Hf}$ & 5.1 & 5.31 & 4 & 5.3 & 4.97 & -7 & 2.4 & 2.38 & -1 & 1.6 & 2.00 & 20 & 4.8 & 4.81 & 0 & & 5.76 & & 3.91 & 3.83 & -2 \\
\hline $\mathrm{Ta}$ & 0.99 & 0.93 & -6 & 0.98 & 0.85 & -15 & 0.15 & 0.14 & -7 & 0.095 & 0.11 & 14 & 0.63 & 0.57 & -11 & & 0.66 & & 0.367 & 0.35 & -5 \\
\hline $\mathrm{Pb}$ & & 52.8 & & & 74.5 & & & 4.96 & & & 6.35 & & & 18.0 & & & 19.0 & & & 12.0 & \\
\hline Th & 78.3 & 87.4 & 10 & 82.4 & 85.2 & 3 & 4.3 & 4.82 & 11 & 2.3 & 3.29 & 30 & & 21.5 & & 23.5 & 24.4 & 4 & 9.5 & 9.07 & -5 \\
\hline U & 15.1 & 15.7 & 3.82 & 15.7 & 15.5 & -1 & 1.17 & 1.20 & 3 & 0.56 & 0.83 & 33 & & 3.99 & & 4.43 & 4.48 & 1 & 2.33 & 2.20 & -6 \\
\hline & Footnote: & & & & & & & & & & & & & & & & & & & & \\
\hline & difff in $\%$ & rence & veen pu & shed valu & and ne & alues re & ve to the & MS & & & & & & & & & & & & & \\
\hline & - The last $\mathrm{co}$ & umn sur & larizes the & relative dey & ations be & ween publis & hed values & nd new & ies. It $\mathrm{w}$ & evaluate & 1 stan & d devia & of all dit & ces $\mathrm{i}$ & & & & & & & \\
\hline & - Difference & etwee & onsted & des and $r$ & $\begin{array}{l}N \text { value } \\
\text { S }\end{array}$ & e sometim & nes quite lar & & & & & & & & & & & guisitic & thod & & \\
\hline & $\begin{array}{l}\text { and year of } \\
\text { - The publis }\end{array}$ & ed data & from $D e$ & nt et al. (1) & $\begin{array}{l}\text { blished } \\
\text { 9). Defa }\end{array}$ & et al. (19 & 10) and $\mathrm{McD}$ & otte & 1993) & & & & & & & & & & & & \\
\hline
\end{tabular}




\begin{tabular}{|c|c|c|c|c|c|c|c|c|c|c|c|c|c|c|c|c|c|c|c|c|c|}
\hline \multirow{3}{*}{$\begin{array}{l}\text { Location } \\
\text { Sample name } \\
\text { Conc. in ppm }\end{array}$} & \multirow[b]{3}{*}{ published } & \multirow{3}{*}{$\begin{array}{l}\text { B80 } \\
\text { new }\end{array}$} & \multirow[b]{3}{*}{ diff in $\%$} & \multirow[b]{3}{*}{ published } & \multirow{3}{*}{$\begin{array}{l}\text { B88 } \\
\text { new }\end{array}$} & \multirow[b]{3}{*}{ diff in \% } & \multicolumn{6}{|c|}{ Babuyan } & \multicolumn{3}{|c|}{ Camiguin } & \multicolumn{6}{|c|}{ Cagua } \\
\hline & & & & & & & & BB20 & & & BB39 & & & CM54 & & & CA 9 & & & CA 26 & \\
\hline & & & & & & & published & new & diff in $\%$ & published & new & diff in $\%$ & published & new & diff in $\%$ & published & new & diff in \% & published & new & diff in $\%$ \\
\hline $\mathrm{Cr}$ & 28 & & & 69 & & & 23 & & & & & & 25 & & & & & & & & \\
\hline $\mathrm{Ni}$ & 28 & & & 62 & & & 16 & & & & & & 11 & & & & & & & & \\
\hline Co & 34 & 33.3 & -2 & & 22.1 & & 21 & 21.6 & 3 & & 30.2 & & 19 & 18.3 & -4 & & 14.0 & & & 18.6 & \\
\hline $\mathrm{Rb}$ & 27 & 27.7 & 3 & 19 & 113 & 83 & 31 & 36.8 & 16 & & 17.9 & & 30 & 31.5 & 5 & 25 & 28.4 & 12 & 23 & 25.1 & 8 \\
\hline $\mathrm{Sr}$ & 472 & 492 & 4 & 503 & 587 & 14 & 308 & 301 & -2 & & 378 & & 478 & 507 & 6 & 553 & 634 & 13 & 472 & 529 & 11 \\
\hline$Y$ & 31 & 14.4 & -115 & 29 & 19.6 & -48 & & 17.4 & & & 14.7 & & & 19.8 & & & 20.0 & & & 19.5 & \\
\hline $\mathrm{Zr}$ & 275 & 82.3 & -234 & 233 & 253 & 8 & 79 & 87.8 & 10 & & 48.0 & & 103 & 97.2 & -6 & & 63.8 & & & 62.9 & \\
\hline $\mathrm{Nb}$ & 3.6 & 3.61 & 0 & 12.5 & 13.9 & 10 & & 3.19 & & & 1.78 & & & 3.17 & & & 4.32 & & & 3.47 & \\
\hline Cs & & 1.32 & & & 3.61 & & & 0.77 & & & 1.11 & & & 2.39 & & & 1.49 & & & 1.52 & \\
\hline $\mathrm{Ba}$ & 632 & 288 & -119 & 569 & 657 & 13 & 185 & 222 & 17 & & 179 & & 300 & 325 & 8 & 505 & 501 & -1 & 408 & 406 & 0 \\
\hline $\mathrm{La}$ & 14 & 12.7 & -10 & 36 & 34.1 & -6 & 14.6 & 15.9 & 8 & 10 & 10.6 & 6 & 22 & 21.6 & -2 & 15.92 & 14.7 & -8 & 13.04 & 11.8 & -11 \\
\hline $\mathrm{Ce}$ & 29 & 29.0 & 0 & 81 & 80.3 & -1 & 30.8 & 32.6 & 6 & 20.2 & 22.5 & 10 & 42.5 & 43.1 & 1 & 42.5 & 27.5 & -55 & 27.3 & 22.2 & -23 \\
\hline $\mathrm{Pr}$ & & 3.91 & & & 10.5 & & & 4.19 & & & 2.99 & & & 5.32 & & & 3.39 & & & 2.98 & \\
\hline $\mathrm{Nd}$ & 17 & 16.9 & -1 & 44 & 40.6 & -8 & & 16.7 & & & 12.1 & & & 20.7 & & 14.82 & 13.8 & -7 & 12.63 & 12.2 & -4 \\
\hline $\mathrm{Sm}$ & 3.5 & 3.51 & 0 & & 6.81 & & 2.9 & 3.60 & 19 & 2.3 & 2.80 & 18 & 3.6 & 4.03 & 11 & 3.79 & 3.03 & -25 & 3.03 & 2.91 & -4 \\
\hline Eu & 0.91 & 0.92 & 1 & 1.5 & 1.45 & -3 & 1.02 & 0.97 & -5 & 0.85 & 0.85 & 0 & 1.19 & 1.14 & -4 & & 0.95 & & & 0.95 & \\
\hline $\mathrm{Gd}$ & 2.8 & 2.81 & 0 & 4.8 & 4.41 & -9 & & 3.09 & & & 2.64 & & & 3.75 & & & 3.27 & & & 2.95 & \\
\hline $\mathrm{Tb}$ & 0.37 & 0.41 & 10 & & 0.59 & & 0.39 & 0.46 & 15 & 0.33 & 0.39 & 15 & 0.48 & 0.55 & 13 & & 0.49 & & & 0.47 & \\
\hline Dy & 2.4 & 2.44 & 2 & 3.35 & 3.26 & -3 & & 2.71 & & & 2.40 & & & 3.13 & & & 2.95 & & & 2.96 & \\
\hline Ho & & 0.50 & & & 0.66 & & & 0.58 & & & 0.52 & & & 0.65 & & & 0.66 & & & 0.67 & \\
\hline $\mathrm{Er}$ & 1.5 & 1.42 & -6 & 1.9 & 1.93 & 2 & & 1.59 & & & 1.47 & & & 1.95 & & & 2.02 & & & 1.95 & \\
\hline $\mathrm{Yb}$ & 1.45 & 1.36 & -7 & 1.95 & 1.85 & -5 & 1.7 & 1.60 & -6 & 1.55 & 1.39 & -12 & 2 & 1.90 & -5 & 2.08 & 1.97 & -6 & 1.81 & 1.91 & 5 \\
\hline Lu & & 0.21 & & & 0.29 & & & 0.26 & & & 0.23 & & & 0.28 & & & 0.29 & & & 0.31 & \\
\hline $\mathrm{Hf}$ & 2.25 & 2.24 & 0 & & 6.34 & & 2.3 & 2.34 & 2 & & 1.35 & & 1.55 & 2.49 & 38 & & 1.81 & & & 1.71 & \\
\hline $\mathrm{Ta}$ & 0.23 & 0.20 & -15 & & 0.78 & & 0.19 & 0.19 & 0 & 0.11 & 0.10 & -10 & 0.19 & 0.17 & -12 & & 0.24 & & & 0.21 & \\
\hline $\mathrm{Pb}$ & & 7.30 & & & 15.3 & & & 10.1 & & & 7.45 & & & 7.05 & & & 7.52 & & & 5.82 & \\
\hline Th & 4.7 & 4.94 & 5 & 33.3 & 34.3 & 3 & 4.6 & 5.03 & 9 & 2.9 & 2.93 & 1 & 6.4 & 6.35 & -1 & & 3.98 & & & 3.16 & \\
\hline U & 0.97 & 0.92 & -5 & & 5.38 & & 1 & 1.06 & 6 & & 0.58 & & 1.35 & 1.26 & -7 & & 1.02 & & & 0.95 & \\
\hline
\end{tabular}




\begin{tabular}{c|ccc|c|}
\hline $\begin{array}{c}\text { Location } \\
\text { Sample name } \\
\text { Conc. in ppm }\end{array}$ & \multicolumn{3}{|c|}{$\begin{array}{c}\text { Baguio } \\
\text { 47A }\end{array}$} & published \\
new & diff in \% & $\begin{array}{c}\text { Standard deviation } \\
\text { of the differences }\end{array}$ \\
\hline $\mathrm{Cr}$ & 7 & & & \\
$\mathrm{Ni}$ & & & & \\
$\mathrm{Co}$ & & 30.1 & & $\mathbf{1 8}$ \\
$\mathrm{Rb}$ & 19 & 19.7 & $\mathbf{4}$ & $\mathbf{2 2}$ \\
$\mathrm{Sr}$ & 506 & 519 & $\mathbf{3}$ & $\mathbf{1 5}$ \\
$\mathrm{Y}$ & & 28.0 & & $\mathbf{5 8}$ \\
$\mathrm{Zr}$ & & 101 & & $\mathbf{7 3}$ \\
$\mathrm{Nb}$ & & 3.8 & & $\mathbf{6}$ \\
$\mathrm{Cs}$ & & 0.49 & & \\
$\mathrm{Ba}$ & 227 & 249 & $\mathbf{9}$ & $\mathbf{3 5}$ \\
$\mathrm{La}$ & 13.1 & 13.0 & $\mathbf{- 1}$ & $\mathbf{9}$ \\
$\mathrm{Ce}$ & 26.2 & 27.5 & $\mathbf{5}$ & $\mathbf{1 7}$ \\
$\mathrm{Pr}$ & & 4.10 & & \\
$\mathrm{Nd}$ & 18.8 & 18.4 & $\mathbf{- 2}$ & $\mathbf{2 6}$ \\
$\mathrm{Sm}$ & 4 & 4.53 & $\mathbf{1 2}$ & $\mathbf{1 4}$ \\
$\mathrm{Eu}$ & 1.55 & 1.40 & $\mathbf{- 1 1}$ & $\mathbf{9}$ \\
$\mathrm{Gd}$ & 4.2 & 4.89 & $\mathbf{1 4}$ & $\mathbf{5 6}$ \\
$\mathrm{Tb}$ & 0.7 & 0.73 & $\mathbf{4}$ & $\mathbf{7}$ \\
$\mathrm{Dy}$ & 4.3 & 4.34 & $\mathbf{1}$ & $\mathbf{6}$ \\
$\mathrm{Ho}$ & 0.94 & 0.95 & $\mathbf{1}$ & \\
$\mathrm{Er}$ & 2.4 & 2.63 & $\mathbf{9}$ & $\mathbf{4}$ \\
$\mathrm{Yb}$ & 2.4 & 2.40 & $\mathbf{0}$ & $\mathbf{2 2}$ \\
$\mathrm{Lu}$ & 0.43 & 0.37 & $\mathbf{- 1 6}$ & $\mathbf{1 7}$ \\
$\mathrm{Hf}$ & & 2.70 & & $\mathbf{1 4}$ \\
$\mathrm{Ta}$ & & 0.21 & & $\mathbf{9}$ \\
$\mathrm{Pb}$ & & 4.61 & & \\
$\mathrm{Th}$ & 3 & 2.59 & $\mathbf{- 1 6}$ & $\mathbf{1 1}$ \\
$\mathrm{U}$ & 0.9 & 0.81 & $\mathbf{- 1 1}$ & $\mathbf{1 2}$ \\
& & & &
\end{tabular}

